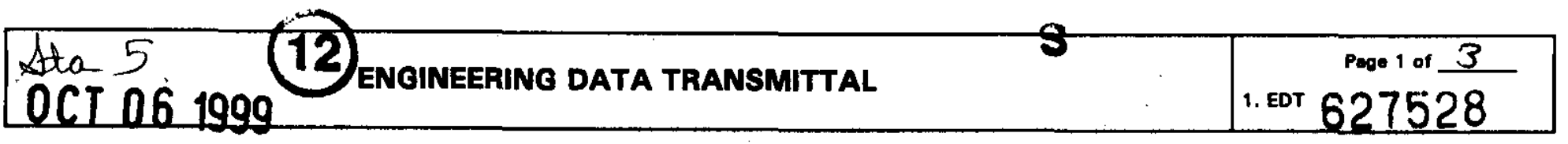

\section{To: (Receiving Organization) \\ DISTRIBUTION}

5. Proj./Prog./Dept./Div.:

PFP Radiological Engineering

8. Originator Remarks:

This document is being released to provide a technical basis for work place air monitoring at PFP.

\section{Receiver Remarks:}

Eor release.

\begin{abstract}
3. From: (Originating Organization)
PEP Radiological Control
\end{abstract}

6. Design Authority/Design Agent/Cog. Engr.:

RA Jones

\author{
4. Related EDT No.: \\ NA \\ 7. Purchase Order No.: \\ NA \\ 9. Equip./Component No.: \\ NA \\ 10. System/Bldg./Facility: \\ PFP \\ 12. Major Assm. Dwg. No.: \\ NA \\ 13. PermitPermit Application No.: \\ NA \\ 14. Required Response Date:
}

NA

\begin{tabular}{|c|c|c|c|}
\hline (F) & (G) & (H) & (l) \\
\hline $\begin{array}{l}\text { Agproval } \\
\text { Dessig: } \\
\text { nator }\end{array}$ & $\begin{array}{c}\text { Reason } \\
\text { for Trans- } \\
\text { mittal }\end{array}$ & $\begin{array}{c}\text { Origi- } \\
\text { nator } \\
\text { Dispo- } \\
\text { stion }\end{array}$ & $\begin{array}{c}\text { Receiv- } \\
\text { er } \\
\text { Dispo- } \\
\text { sition }\end{array}$ \\
\hline 5 & & & \\
\hline
\end{tabular}

\begin{tabular}{|l|l|}
\hline \multicolumn{2}{|c|}{15.} \\
\hline $\begin{array}{c}\text { (A) } \\
\text { Item } \\
\text { No. }\end{array}$ & (B) Document/Drawing No. \\
\hline 1 & HNF-5242 \\
\hline & \\
\hline & \\
\hline & \\
\hline & \\
\hline & \\
\hline & \\
\hline
\end{tabular}

DATA TRANSMITTED

\begin{tabular}{|c|c|c|}
$\begin{array}{c}\text { (C) Sheet } \\
\text { No. }\end{array}$ & $\begin{array}{c}\text { (D) Rev. } \\
\text { No. }\end{array}$ & (E) Title or Description of Data Transmitted \\
\hline
\end{tabular}

\begin{tabular}{|l|l|l} 
NA & 0 & Tech. Basis for WPAM a PFP
\end{tabular}

16.

\begin{tabular}{|c|l|}
\hline Approval Designator (F) & \\
\hline $\begin{array}{c}\text { E S, Q } D \text { OR N/A } \\
(\text { See WHC-CM-3-5, } \\
\text { Sec. 12.7) }\end{array}$ & $\begin{array}{l}\text { 1. Approval } \\
\text { 2. Release }\end{array}$ \\
\hline
\end{tabular}

17.

\begin{tabular}{|l|l|l|}
\hline NA & 0 & Tech. Basis for WPAM a PFP \\
\hline & & \\
\hline & & \\
\hline & & \\
\hline & & \\
\hline
\end{tabular}

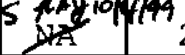

KEY
Disposition (H) \& (I)

\section{Approved \\ 2. Approved w/comment \\ 4. Reviewed no/comment \\ 5. Reviewed w/comment}

3. Disapproved w/comment

6. Receipt acknowledged
(See Approval Designator for required signatures)

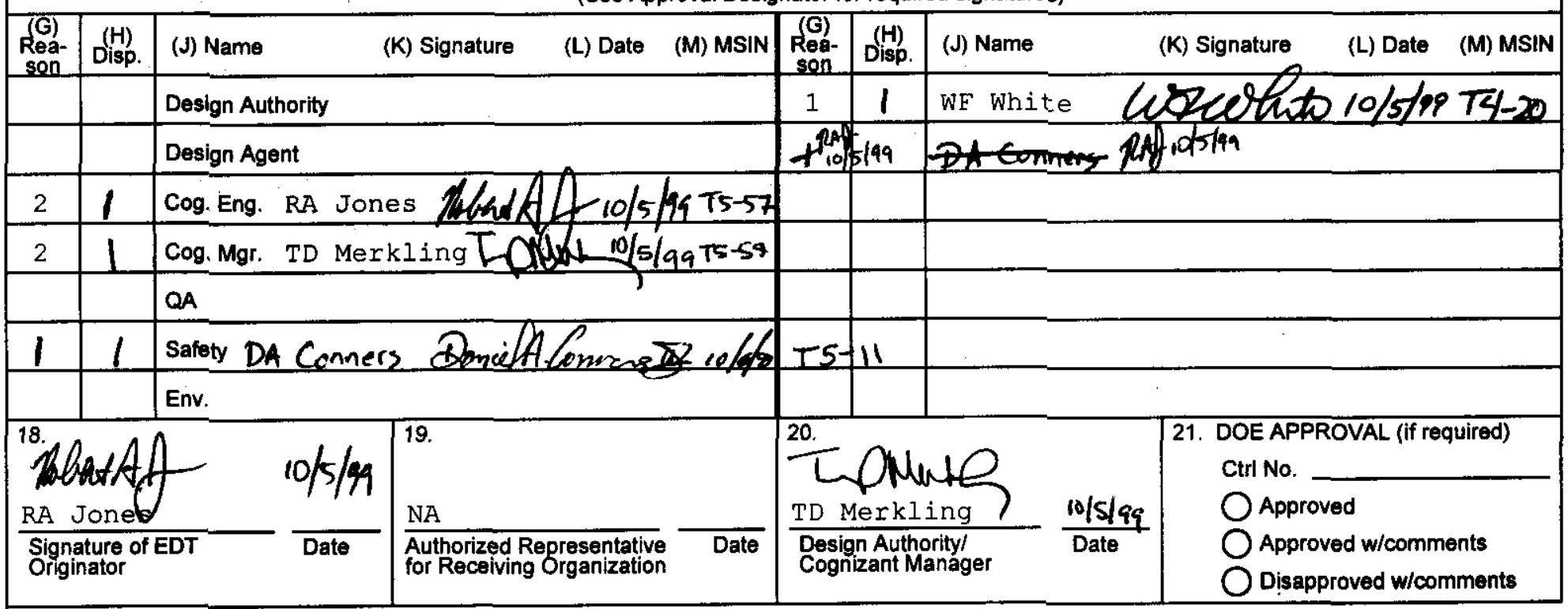




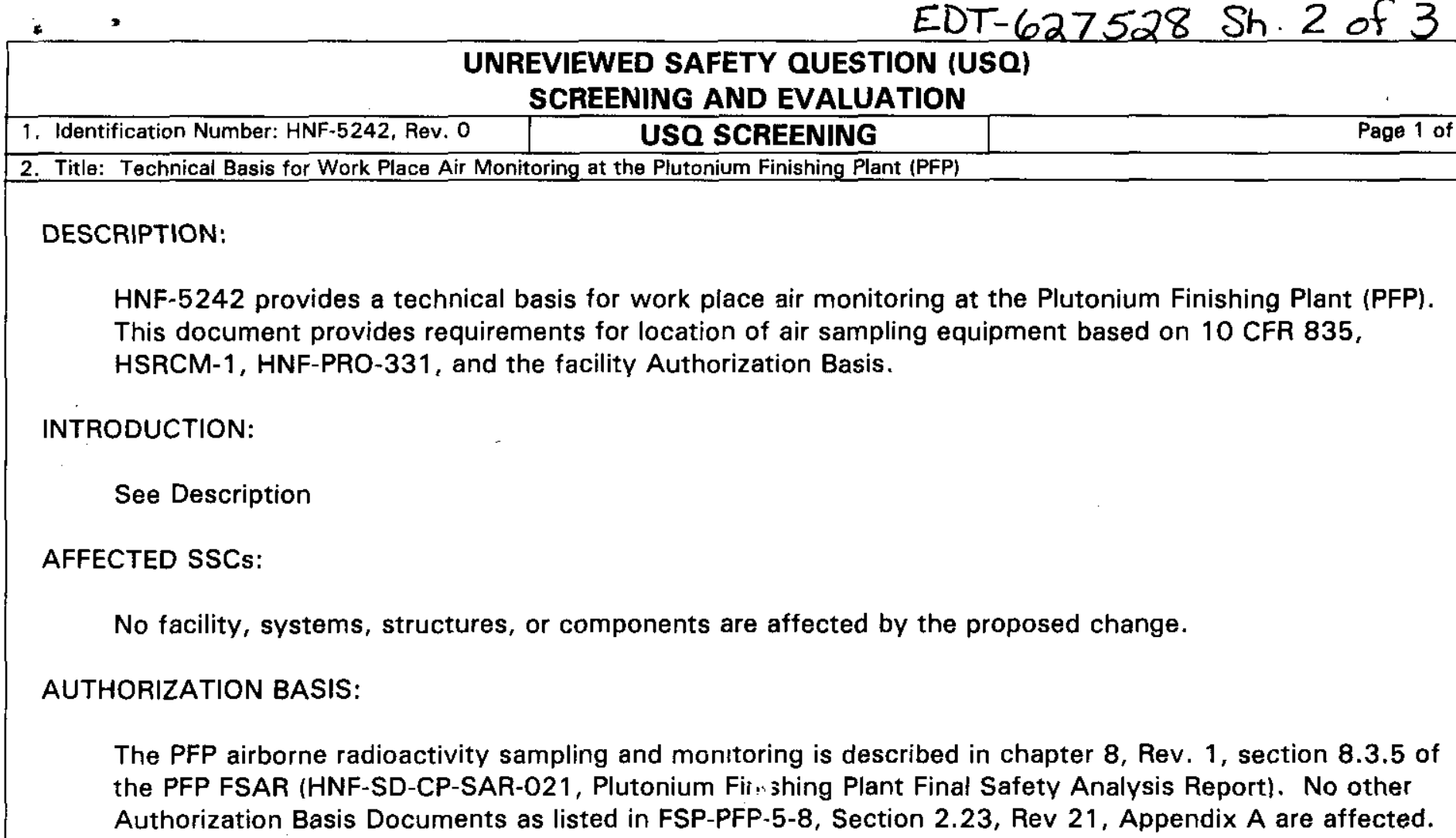

\section{CONCLUSION:}

All USO screening questions can be answered "no," therefore an Unreviewed Safety Question Evaluation will not be required.

REFERENCES: N/A

Instructions: Respond to each question and provide justification for each response. A restatement of the question does not constitute a satisfactory justification or basis. An adequate justification provides sufficient explanation such that an independent reviewer could reach the same conclusion based on the information provided [DOE $5480.21,10 . e .1$ ].

\section{QUESTIONS}

1. Does the proposed change or occurrence represent a change to the Facility or procedures as described in the Authorization Basis? [] N/A [ X] No [] Yes/Maybe

BASIS: Chapter 8, Section 8.3.1.7 (and various other places) of the PFP FSAR state that Fixed Head Samplers (FHS) are required for sampling airborne contamination levels that may exceed $2 \%$ of the applicable annual limit of intake (ALI). This section also states that CAMs are required for sampling airborne contamination levels that may exceed the applicable DAC guides. The proposed change describes which rooms CAMs and FHS are required based on these criteria. Section 8.3.5 of the PFP FSAR states that the work space air sampling and monitoring is reviewed annually. The proposed document is part of that annual review to ensure compliance with applicable regulations and guidelines. The proposed change does not represent a change to the facility or procedures as described in the current FSAR. Therefore, the answer to this question is "No."

2. Does the proposed change or occurrence represent conditions that have not been analyzed in the Authorization Basis?

[] N/A [X] No [] Yes/Maybe

BASIS: See response to \#1 above. No conditions ar: change is part of the annual review as described in $\varepsilon$

3. Does the proposed change represent a test or experiment NOr des beo in the Authorization Basis that may affect the safe operation of the facility?

[X] N/A [] No [] Yes/Maybe ntroduced by the procedure change. The proposed 5. Therefore, the answer to this question is "No." 
1. Identification Number: HNF-5242, Rev. 0

BASIS: The proposed change is not a test or experiment.

4. Does the proposed change or occurrence represent a change to the Technical Safety Requirements or a reduction in the margin of safety defined in the Technical Safety Requirements?

[] N/A [X] No [] Yes/Maybe

BASIS: This proposed change is a descriptive document stating where CAMs and FHS are required. This document is also based on the current national regulations and standards. This proposed change does not affect any OSR/TSR/LCO or AC in the WHC-SD.CP-SSR-010, "Plutonium Finishing Plant Operational Safety Requirements," Rev. O-K. Therefore, no change ts any TSR, OSR, or margin of safety is involved with the proposed procedure change.

USOE \#1

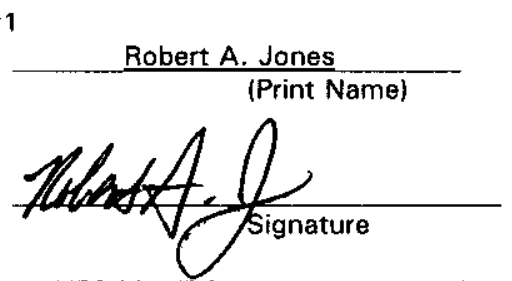

Date:
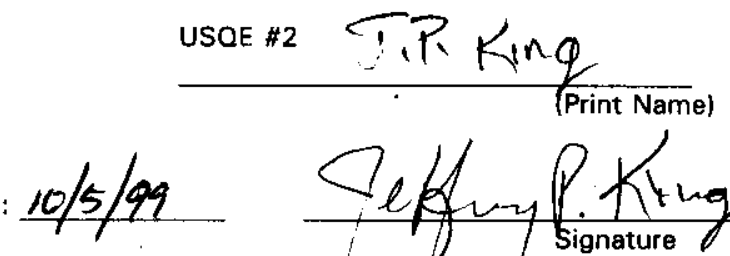

If there is a YES/MAYBE response to questions $1,2,3$, or 4 , then a USO Evaluation must be completed.

The following guidance should be considered when completing this screening. This guidance should not be considered all-inclusive; additional factors may need to be considered depending on the nature of the proposed change.

Does the proposed change:

1) Modify, add, or delete a safety class function of a structure, s; stem c ccmponent stated in the authorization basis?

2) Alter the design of a structure, system, or component as described in the authorization basis?

3) Modify, add, or delete the description of operation, operating environment, or analyses of any system or component described in the authorization basis?

4) Modify, add, delete or conflict with any of the design bases stated in the authorization basis?

5) Conflict with the principle or general design criteria stated in the authorization basis?

6) Modify, add, or delete any plant design features described in the authorization basis?

7) Modify, add, or delete a flow diagram or facility drawing provided in the authorization basis?

8) Create the potential for a new system or component interactions (e.g., seismic, electrical breaker coordination)? 


\title{
Technical Basis for Work Place Air Monitoring for the Plutonium Finishing Plant (PFP)
}

\section{R. A. Jones}

Babcock and Wilcox Hanford Co.

Richland, WA 99352

U.S. Department of Energy Contract DE-AC06-96RL13200

\author{
EDT/ECN: $E D T-627528 \quad$ UC: 2000 \\ Org Code: 15E30 Charge Code: 110749 \\ B\&R Code: EW3130000 Total Pages: 49
}

Key Words: CAM, Fixed Head, Air Sample, Staplex, Air Monitor, DAC, ALI, Eberline, Canberra

\begin{abstract}
Eberline is a registered Trademark of Eberline Industries - Canberra and Canberra Alpha Sentry are registered Trademarks of Canberra Industries -Staplex is a registered Trademark uf The Staplex Company, Inc. -Tygon is a registered Trademark of Norton Perfomance Plastics Corperation
\end{abstract}

TRADEMARK DISCLAIMER. Reference herein to any specific commercial product, process, or service by trade name, trademark, manufacturer, or otherwise, does not necessarily constitute or imply its endorsement, recommendation, or favoring by the United States Government or any agency thereof or its contractors or subcontractors.

Printed in the United States of America. To obtain copies of this document, contact: Document Control Services, P.O. Box 950, Mailstop H6-08, Richland WA 99352, Phone (509) 372-2420; Fax (509) 376-4989.

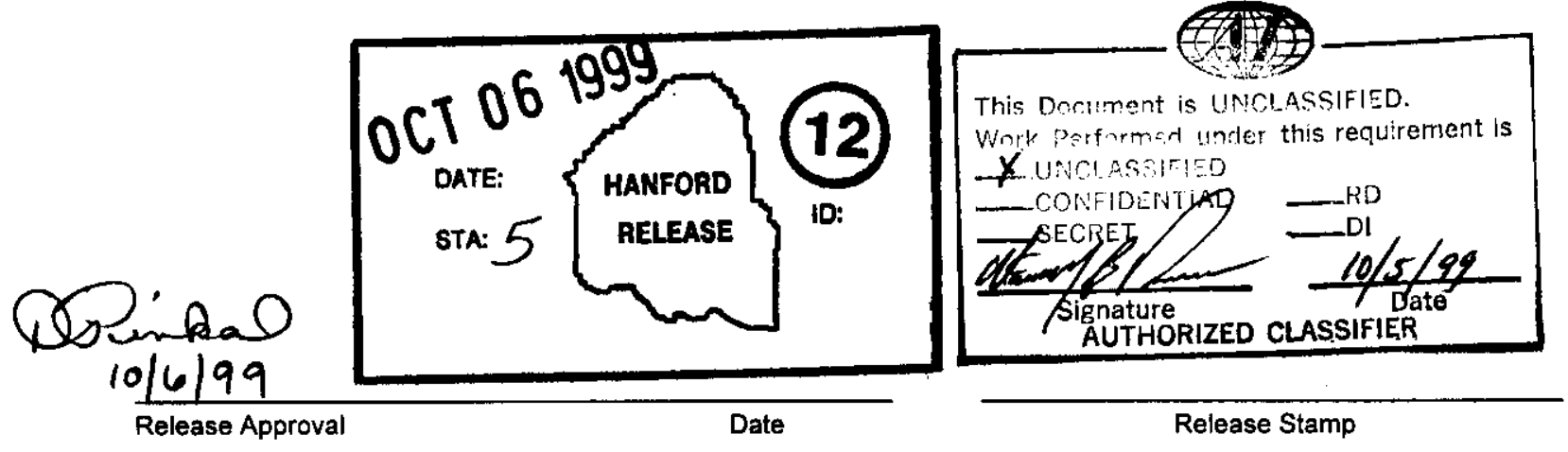


TECHNICAL BASIS FOR WORK PLACE AIR MONITORING AT THE PLUTONIUM FINISHING PLANT (PFP)

\author{
HNF-5242 \\ REVISION: 0
}

AUTHOR: $\quad$ ROBERT A. JONES 


\section{Technical Basis for Work Place Air Monitoring at the Plutonium Finishing Plant (PFP)}

\section{Table of Contents}

1. Purpose

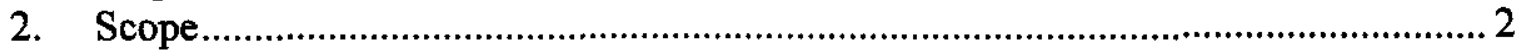

3. Technical Basis for Work Place Air Monitoring ......................................................... 2

3.1. Work Place Air Sampling .............................................................................. 3

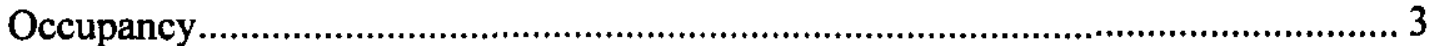

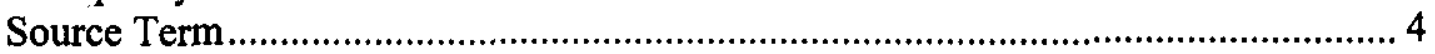

3.2. Work Place Air Monitoring using CAMs …………....................................... 6

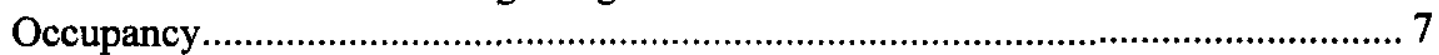

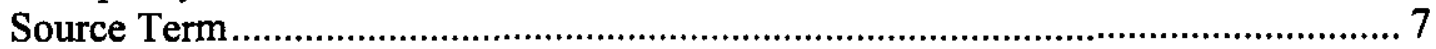

Vault Monitoring ……........................................................................................ 8

3.3. Placement and Selection of Air Monitoring Equipment ......................................... 8

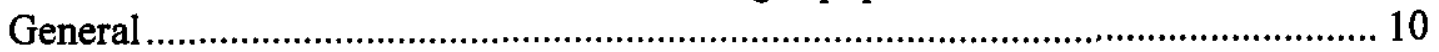

Air Sample Minimum Detectable Concentration ....................................................... 12

Sample Line Loss............................................................................................ 12

Selection of Air Sample Filters........................................................................ 13

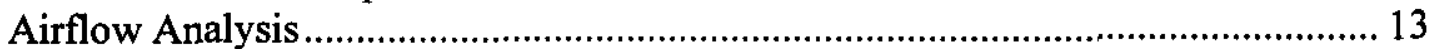

3.4. Tracking and Trending Program ....................................................................... 14

4. Required Air Monitoring at the PFP Complex …….............................................. 15

5. Required Review................................................................................................ 34

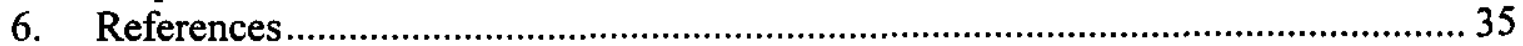

6.1 Facility Air Monitoring References .................................................................. 35

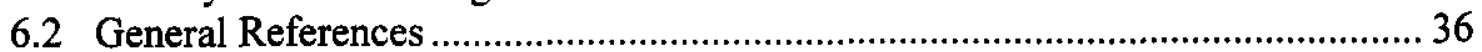

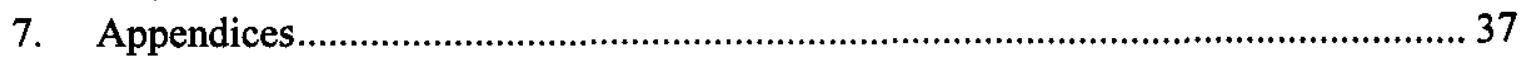




\section{Purpose}

This document establishes the basis for the Plutonium Finishing Plant's (PFP) work place air monitoring program in accordance with the following requirements:

- Title 10, Code of Federal Regulations (CFR), Part 835 "Occupational Radiation Protection"

- Hanford Site Radiological Control Manual (HSRCM-1)

- HNF-PRO-331, Work Place Air Monitoring

- WHC-SD-CP-SAR-021, Plutonium Finishing Plant Final Safety Analysis Report

- Applicable recognized national standards invoked by DOE Orders and Policies.

\section{Scope}

The criteria, standards, and requirements contained in this technical basis apply to airborne radioactive particulate sampling measuring and monitoring in the workplace under normal operating conditions within the PFP facility. Guidance for placement of air sampling and monitoring equipment will be given. Situation based air monitoring needs (such as maintenance and de-activation activities) should be derived from guidance provided by this technical basis. Air monitoring needs for these activities should be addressed in work plans and/or radiological work permits.

Not within the scope of this technical basis:

- Air sampling and monitoring for facility effluent streams

- Environmental ambient air sampling and monitoring

\section{Technical Basis for Work Place Air Monitoring}

HNF-PRO-331, Work Place Air Monitoring provides direction for when air monitoring is required. In general, purposes for work place air monitoring are:

- Demonstrating regulatory compliance

- Documenting radiological conditions

- Detecting changes in radiological conditions

- Detecting the gradual buildup of airborne radioactive material

- Verifying the effectiveness of engineering controls in preventing or reducing levels of airborne radioactive material

This technical basis will include the basis for selection and placement of air sampling and monitoring equipment. This will include providing rationale for placing air samplers and 
monitors, addressing sample transport line losses where applicable and direction to facility maps showing locations of air monitoring equipment.

\subsection{Work Place Air Sampling}

Work place air sampling is required to be performed if the area is classified as occupied (infrequently occupied or continuously occupied), and an individual is likely to receive an annual intake of 2 percent or more of the specific annual limit on intake (ALI). 2 percent of an ALI is equivalent to 40 Derived Air Concentration (DAC) hours. A combination of the following activities/documentation should be used when determining the need for air sampling:

- Air sample data

- Radiological survey data

- Source term(s)

- Release potential of the source term(s)

- Containment or confinement of the source term(s)

- Radiological work permit (RWP) constraints

- Occupancy times

Use grab/breathing air samples, when cost effective to monitor infrequently occupied areas. This practice allows for better representation of workers breathing zone ${ }^{1}$.

\section{Occupancy}

HNF-PRO-331 glossary describes several occupancy classes. To be defined as occupied, personnel must be present for an average of 96 minutes per day, 8 hours per week, 104 hours per quarter, 416 hours per calendar year or more. Occupancy is the true rate and can be converted to other time intervals as needed. Once occupancy is established, there are two classes described:

- Infrequently occupied areas are occupied areas where workers are present less than 2000 hours per year

- Continuous occupancy means that a worker could occupy an area for 2000 hours per year or more

Occupancy classes allow for the use of administrative controls instead of air sampling. For example, if a room is considered not occupied, then air sampling is not required in that room. HSRCM-1, Article 316 requires consideration of respiratory protection under the following conditions:

- Entry into posted Airborne Radioactivity Areas (ARA)

\footnotetext{
1 "Breathing zone" is defined as the general volume of air breathed by the worker, usually at a height of 1 to 2 meters.
} 
- During breach of contaminated systems or components

- Work in areas or on equipment with removable contamination levels greater than 100 times the values in HSRCM-1 Table $2-2\left(2000-\mathrm{dpm} / 100 \mathrm{~cm}^{2}\right.$ for $\left.{ }^{239} \mathrm{Pu}\right)$

- During work on contaminated or activated surfaces with the potential to generate airborne radioactivity

The trigger level (according to HSRCM-1, Articles 223 and 235) for posting an ARA is 10 percent of a DAC. At this level, an individual entering an area less than the times considered occupied would receive less than 40 DAC-hrs in a working year ${ }^{2}$. This is the limit for requiring air sampling. If airborne concentrations are above 10 percent of a DAC, then air sampling is required for entry because of the potential to exceed $40 \mathrm{DAC}$-hrs exposure to an individual entering the room classified as nonoccupied.

If the area is defined as occupied, occupancy time and predicted airborne concentration may be used to determine the need for air sampling. The following examples may be used to determine when air sampling is required:

- $4.0 \mathrm{E}-14 \mu \mathrm{Ci} / \mathrm{ml}$ for ${ }^{239} \mathrm{Pu}$ integrated over one working year (2000 hours)

- $8.0 \mathrm{E}-14 \mu \mathrm{Ci} / \mathrm{ml}$ for ${ }^{239} \mathrm{Pu}$ integrated over 1000 hours in one working year

\section{Source Term}

PNL-MA-552, Hanford Internal Dosimetry Project Manual contains a table, referenced by HSRCM-1 in table H5-1 that describes when bioassay should be considered. These are based on the same trigger level that is required for air sampling (2 percent of an ALI exposure in one year). The table below is adapted from table H5-1 in the HSRCM-1 for ${ }^{239} \mathrm{Pu}^{3}$ :

Table 1

\begin{tabular}{|c|c|}
\hline Source Term Criteria for Considering Air Sampling \\
\hline Containment & Activity $(\boldsymbol{\mu C i})$ \\
\hline Fume Hood & 1 \\
\hline Glovebox & 10 \\
\hline
\end{tabular}

${ }^{2}$ Dose evaluations are considered for individuals on a working year basis, defined as 2000 hours. If an individual is present in a room for 416 hours in a working year, then the other times defining occupancy have been exceeded (See definitions for Occupancy in Section 3.1)

${ }^{3} \mathrm{PFP}$ primarily contains weapons-grade plutonium. The most restrictive DAC value of $2 \mathrm{E}-12 \mathrm{uCi} / \mathrm{ml}$ is used for ${ }^{239} \mathrm{Pu}$. ${ }^{241} \mathrm{Am}$ in-growth is also present. Because the DAC value is the same activity, ${ }^{239} \mathrm{Pu}$ is stated as the isotope of interest. 
General activities for fume hoods and gloveboxes have been determined, based on percent release fraction potentials of powder source term likely to expose workers to 2 percent of an ALI. This table should be used for determining which rooms require air sampling. In general, all fume hoods and gloveboxes at the PFP (with some exceptions) should be considered as exceeding the values in Table 1 .

HNF-PRO-331 provides guidance for trigger levels requiring air sampling based on airborne suspension (re-suspension) of surface contamination. This document provides three basic suspension factors:

- $1.0 \mathrm{E}-5 / \mathrm{m}-$ For non-heat generating aggressive work such as sweeping

- $1.0 \mathrm{E}-6 / \mathrm{m}$ - For minimal activities such as general inspection/surveillance

- $1.0 \mathrm{E}-7 / \mathrm{m}-$ For stationary working conditions

Using these values for re-suspension of loose surface contamination, air sampling should be considered where the following contamination is present:

- $88-\mathrm{dpm} / 100 \mathrm{~cm}^{2}$ for non-heat generating aggressive work

- $880-\mathrm{dpm} / 100 \mathrm{~cm}^{2}$ for minimal activities

- $8800-\mathrm{dpm} / 100 \mathrm{~cm}^{2}$ for stationary work activities

These values may be modified by accounting for several factors such as (but not limited to):

- Chemical form

- Particle size

- Ventilation

- Work scope

- Total radioactivity

- Occupancy time

In general, minimal activities will be considered, and a loose surface contamination value of $880-\mathrm{dpm} / 100 \mathrm{~cm}^{2}$ will be used (from a suspension factor of $1 \mathrm{E}-6 / \mathrm{m}$ ). This is inherently conservative because of the assumptions used to derive the suspension factors: an enclosed air space, lacking ventilation, with uniformly distributed removable contamination across the horizontal floor surface.

Some source term at the PFP is contained in physical structures designed to prevent release. Some examples of this are:

- Piping

- Ducting

- Permanently sealed systems

Air sampling should be considered in areas where significant amounts of source term (determined by risk analysis) exist, taking into consideration occupancy time, 
historical data and other radiological surveys. Risk is calculated by multiplying the potential airborne concentration by the probability of material release. Because the PFP is an aging facility, some systems yield higher risk of release than newer systems. This should be taken into account when prescribing air sampling. The purpose for air sampling in these areas is to monitor the effectiveness of engineered barriers. Routine radiological surveys may be used instead of continual air sampling for these areas.

Transport only areas (such as corridors and rooms not normally containing radioactive material) do not require air sampling. Because these areas are generally considered continuously occupied, source term occupancy ${ }^{4}$ is used instead. Engineered controls, radiological surveys, and transport times for the source negate the necessity of conducting air sampling in transport only areas. Corridors and hallways should not be used for storage of source term capable of exposing workers to 2 percent of an ALI.

\subsection{Work Place Air Monitoring using CAMs}

Work place air monitoring using continuous air monitors (CAMs) is required to be performed in occupied $^{5}$ areas where:

- An individual is likely to be exposed to a concentration of airborne radioactivity exceeding one DAC (one DAC averaged over a single eight hour shift is equivalent to eight DAC-hrs) or

- Where there is a need to alert potentially exposed individuals to unexpected increases in airborne radioactivity levels ${ }^{6}$

A combination of the following activities/documents should be used when determining the need for air monitoring:

- Air sample data

- Occupancy time

- Radiological survey data

- Source term(s)

- Release potential of the source term(s)

- Containment or confinement of source term(s)

- RWP constraints

When cost effective; use portable CAMs to monitor infrequently occupied areas. This practice allows for faster alarm response because of work specific placement.

\footnotetext{
${ }^{4}$ Source term occupancy is classified in the same manner as personnel occupancy.

${ }^{5}$ See section 3.1 "Occupancy" for more details.

${ }^{6}$ CAMs are recommended by the WPAM Facility Technical Authority when personnel are required to perform work with respiratory protection assigned for the purposes of potentially changing airborne conditions.
} 


\section{Occupancy}

Criteria for using CAMs based on work and occupancy is as follows:

- $2.0 \mathrm{E}-12 \mu \mathrm{Ci} / \mathrm{ml}$ based on exposure for an eight-hour shift

- $1.6 \mathrm{E}-11 \mu \mathrm{Ci} / \mathrm{ml}$ based on exposure for a one-hour shift (instantaneous)

- $2.7 \mathrm{E}-12 \mu \mathrm{Ci} / \mathrm{ml}$ based on exposure for a six-hour shift

Occupancy time may be used in determining need for CAMs. The exposure trigger level is $8 \mathrm{DAC}$-hrs for requiring CAMs. The use of protection factors for workers wearing respiratory protection may be considered.

Transport only areas (such as corridors and rooms not normally containing radioactive material) do not require air monitoring. Because these areas are generally considered continuously occupied, source term occupancy is used instead. Engineered controls, radiological surveys, and transport times for the source negate the necessity of conducting air monitoring in transport only areas.

\section{Source Term}

Table 1 activities were calculated based on potential release to workers over one working year. Since that amount was 2 percent of an ALI, general release over one working year is 2 percent of a DAC. For source term characterization criteria, a value of fifty times ${ }^{7}$ Table 1 values will be used in considering CAM placement. In general, all fume hoods and gloveboxes at the PFP (with some exceptions) should be considered as exceeding fifty times Table 1 values. Gloveboxes and fume hoods, which are inactive and isolated to prevent use ("pie-plated" - not including gloveboxes with expired or failed gloves), do not require routine CAM coverage.

These values were determined based on actual work with source term. Modifications to CAM considerations may be made based on work with the source term. In cases where $8 \mathrm{DAC}$-hrs releases are possible, but remote, risk analysis may be performed to assess when CAMs are needed.

For removable surface contamination, suspension factors should be used. Using a suspension factor of $1.0 \mathrm{E}-6 / \mathrm{m}$ for minimal activities, the amount of surface contamination to trigger consideration of CAMs is $44.4 \mathrm{E3} \mathrm{dpm} / 100 \mathrm{~cm}^{2}$. This value may be modified based on factors explained in section 3.1. Protection factors of engineered barriers and respirators may also be used to modify these values.

\footnotetext{
${ }^{7}$ Since Table 1 values are interpreted to be likely to release $2 \%$ DAC over 1 working year, 50 times Table 1 values are considered likely to release $1 \mathrm{DAC}$.
} 


\section{Vault Monitoring}

WHC-SD-CP-SAR-021, Plutonium Finishing Plant Final Safety Analysis Report (PFP FSAR) recognizes that primary containment barriers for plutonium bearing materials stored in vaults and the steel food pack cans might be breached by pressurization due to the effects of radiolysis, chemical reactions, or internal thermal energy. Should this occur, the FSAR (Section 9.1.4) establishes that the event would most likely be detected by the room CAMs, and later by personnel inspection. Therefore, CAMs or an equivalent real-time storage container breach-detection system must be used where vault storage is used for plutonium bearing materials. Certain vault storage configurations may be exempted from this requirement provided the materials are over-packed to prevent contamination spread in the event of lost primary containment. Example of these storage configurations includes material stored in DOT shipping containers or equivalent strong tight over-packs. CAMs used in PFP vaults are also included in the facility tracking system, so that statistical data is available.

\subsection{Placement and Selection of Air Monitoring Equipment}

NUREG 1400 and HNF-PRO-331 provide guidance for placement and selection of air monitoring equipment. A (adapted from HNF-PRO-331) description for placement and selection of sampling equipment based on purpose is as follows ${ }^{8}$ :

Table 2

\begin{tabular}{|l|l|l|}
\hline \multicolumn{3}{|c|}{ Sample Function/Location } \\
\hline Purpose of Sampling/Monitoring & $\begin{array}{l}\text { General Placement of } \\
\text { Samplers/Monitors }\end{array}$ & $\begin{array}{l}\text { General } \\
\text { Facility } \\
\text { Application }\end{array}$ \\
\hline $\begin{array}{l}\text { Estimate worker's intake for } \\
\text { calculating internal dose }\end{array}$ & $\begin{array}{l}\text { Sampler located in worker's } \\
\text { breathing zone, near nose and } \\
\text { mouth }\end{array}$ & GAS, FHAS \\
\hline $\begin{array}{l}\text { Identify area needing confinement } \\
\text { control }\end{array}$ & $\begin{array}{l}\text { Sampler in airflow pathway near } \\
\text { actual or potential release point }\end{array}$ & FHAS, GAS \\
\hline $\begin{array}{l}\text { Provide early warning of elevated } \\
\text { airborne release }\end{array}$ & $\begin{array}{l}\text { Continuous air monitor(s) placed } \\
\text { between worker(s) and release } \\
\text { point(s) }\end{array}$ & $\begin{array}{l}\text { CAM, portable } \\
\text { or strategic } \\
\text { placement }\end{array}$ \\
\hline $\begin{array}{l}\text { Test for leakage of radioactive } \\
\text { materials from sealed confinement }\end{array}$ & $\begin{array}{l}\text { Samplers placed downstream of } \\
\text { confinement-control area }\end{array}$ & $\begin{array}{l}\text { FHAS, CAMs, } \\
\text { GAS }\end{array}$ \\
\hline
\end{tabular}

\footnotetext{
${ }^{8}$ This table provides general facility application heading, not in NUREG 1400 . It is to be used as general guidance to match purpose of air sampling.
} 


\begin{tabular}{|l|l|l|}
\hline system & & \\
\hline $\begin{array}{l}\text { Determine total concentration from } \\
\text { many potential release points }\end{array}$ & Downstream at exhaust point & $\begin{array}{l}\text { FHAS, CAMs } \\
\text { at exhauster }\end{array}$ \\
\hline $\begin{array}{l}\text { Determine airborne radioactivity area } \\
\text { status or respiratory protection } \\
\text { adequacy }\end{array}$ & Samplers at worker's location & $\begin{array}{l}\text { FHAS, GAS in } \\
\text { workers } \\
\text { breathing zone }\end{array}$ \\
\hline $\begin{array}{l}\text { Special purposes, e.g., determining } \\
\text { particle size }\end{array}$ & $\begin{array}{l}\text { Case-by-case depending on } \\
\text { airflow patterns }\end{array}$ & Case by Case \\
\hline
\end{tabular}

FHAS $=$ Fixed Head Air Sampling $\quad$ CAM $=$ Continuous Air Monitoring GAS $=$ Grab Air Sampling

Fixed head air sampling is generally used for identifying areas needing confinement control. For this purpose, airflow patterns of the area should be known. Airflow studies, following guidance in NUREG 1400 should be used to place fixed head air samplers. Potential release points should also be known. Other sampling techniques may also be used by the facility, such as grab sampling.

Continuous air monitors are used to provide early warning of elevated airborne release. For prompt warning of an airborne release, the CAM should be placed between the release point, and the workers. Portable CAMs are generally used for this task, however, strategically placed CAMs may also be used. An example of a strategically placed CAM for this purpose is placing the CAM near a glovebox, with a sample line ${ }^{9}$ between the workers and the glovebox. Likewise, a portable CAM may also be used with a sample line near the release point. For placement to be effective, worker location and potential release points should be well known. Other information, such as airflow should also be used.

A variety of methods may be used to test for leakage of radioactive materials from sealed confinement systems. One is to use fixed head air sampling or CAMs. These should be placed downstream of the confinement system at either strategic locations or at the room exhaust. Strategic location is made more effective when factors such as likely release points, worker operations and airflow studies are incorporated.

Place samplers at room exhaust locations to determine total concentration from many potential release points. CAMs or fixed head air sampling may be used for this purpose. This also may serve a dual purpose of testing for leakage from sealed confinement systems. Care should be taken when using this approach alone because single point releases will cause under-representation of worker's breathing zone.

Grab air samples taken in the workers' breathing zone during work is the usual method of determining airborne radioactivity status or respiratory protection

\footnotetext{
${ }^{9}$ See heading "Sample Line Loss" in this section for more details on correct sample line configuration.
} 
adequacy. Programmatic and continuing assessments are usually performed with fixed head air sampling.

Because of low airflow associated with lapel air samplers and the high sensitivity required for most air sampling applications with airborne ${ }^{239} \mathrm{Pu}$, there is currently no lapel air-sampling program at PFP. Also, high DAC environments likely to exceed respiratory protection ${ }^{10}$ (where Lapel air sampling is most useful) are generally not encountered at PFP. Grab and fixed air sampling is currently used at PFP, when bioassay is either unavailable or inadequate, to estimate the worker's intake. Lapel air sampling should be evaluated on a case-by-case basis if planned work may exceed the protection factor of prescribed respiratory protection. Should lapel air sampling be required for planned work, use procedures, maintenance/calibration and training shall also be developed.

\section{General}

Fixed head air samplers perform several functions. Placement should be based on identified function. Generally, fixed head air samplers for breathing zone monitoring should be placed slightly above head height, in front of the worker. For PFP, fixed head air samplers should be installed at the face of the containment device the worker is using, or in the normal breathing zone. Airflow studies, work and release point characterizations are important in the placement of fixed head air samplers. Careful consideration should be given to the placement of air samplers. Drawings identifying locations of fixed head air samplers are found in drawing number $\mathrm{H}-2-80062$, "Air Sampling Locations."

Continuous air monitors are generally used for prompt detection of an airborne release of radioactivity. This function is ideally served when CAMs are placed downstream of the potential release points, and upstream of the workers. This may not be possible because of configuration constraints; so placement of CAMs downstream of release points, or sample lines near release points should be considered. If multiple release points exist in an area, CAMs may be placed at the exhaust of the room. Careful consideration for dilution and adequate response time should be given before placement of CAMs at exhaust points.

CAMs should generally not be used for determining concentrations because of relatively low intrinsic particle collection efficiency as compared to other air samplers. CAMs may be used for tracking and trending purposes, but should not be used for demonstration of applicable airborne radioactivity limits. Historical facility us of CAMs have shown consistent data for event analysis. Drawings identifying locations of CAMs are found in drawing number H-2-80107, "Constant Air Monitor Station Locations."

\footnotetext{
${ }^{10} \mathrm{~A}$ high DAC environment likely to exceed respiratory protection is any environment, where planned radiological work is likely to expose the worker to $>10 \%$ DAC for the duration of work.
} 
Two CAM types are used at PFP: Eberline Alpha 4, 5, 5A and 5 AS series, and the Canberra Alpha Sentry CAM (currently under evaluation). The Eberline series have been used at PFP for over 20 years, and have been approved by the Hanford Instrument Evaluation Committee (this committee approves portable instruments for Hanford). The Canberra Alpha Sentry CAM was developed by the DOE at LANL, Canberra Industries and Texas A\&M University. The system has been tested per ANSI standard N42-17.b and documented in "Independent Evaluation of Los Alamos National Laboratory Continuous Air Monitor Instrumentation at the Inhalation Toxicology Research Institute," prepared by Hoover, Newton, Fencl, and Marcinkovich in November, 1995.

Grab air samplers are generally used for determining airborne radioactivity area status or respiratory protection adequacy. Grab air samplers should be placed near the workers' breathing zone. Two types of grab air samplers are in use at PFP:

- Portable air samplers: Some use batteries, others use outlet power for operation. These generally sample from 0.5 to 5 cubic feet of air per minute. Uses paper filters for collection of airborne particles. Generally used for during job air samples.

- "Staplex" annular kinetic impactor: High volume of air sampled (generally from 20 to 50 cubic feet of air per minute). Uses kinetic impaction to physically segregate plutonium particles from radon progeny particles onto a planchette. This sampler allows for rapid determination of airborne concentration of plutonium because of high volumes and intrinsic radon discrimination. Generally used for short duration jobs or to determine airborne radioactivity status.

More detailed information and guidance for placement of air samplers may be obtained from NUREG 1400. 


\section{Air Sample Minimum Detectable Concentration}

Careful consideration should be given to air sample volume requirements. The Minimum Detectable Concentration (MDC) shall be equal to or less than the applicable limit. The equation for MDC is as follows:

$$
M D C(u C i / m l)=\frac{2.71+3.29 \sqrt{R_{b} T_{g}\left(1+\frac{T_{g}}{T_{b}}\right)}}{(6.29 E 10) E_{c} T_{g} T_{s} E_{f} F}
$$

Where:

$\begin{array}{ll}\mathrm{E}_{\mathfrak{c}}= & \begin{array}{l}\text { Instrument Counting Efficiency }(\% / 100) \text { identified on the } \\ \text { calibration sticker }\end{array} \\ \mathrm{E}_{\mathrm{f}}= & \text { Fractional collection efficiency }(\% \mathrm{Eff}) / 100 \\ \mathrm{~F}= & \text { Air flow rate through the filter }\left(\mathrm{ft}^{3} / \mathrm{min}\right) \\ \mathrm{R}_{b}= & \text { Background count rate }(\mathrm{cpm}) \\ \mathrm{T}_{b}= & \text { Background count time }(\mathrm{min}) \\ \mathrm{T}_{\mathrm{g}}= & \text { Gross sample count time }(\mathrm{min}) \\ \mathrm{T}_{\mathrm{s}}= & \text { Duration of air sample collection (min) }\end{array}$

For PFP, the applicable limit for radiological work is found on the Radiological Work Permit (RWP). Normally, the applicable limit placed on the RWP does not expose the worker to levels greater than 10 percent of a DAC ${ }^{11}$. A during-job, grab air sample in an ARA allows for a higher MDC (per the RWP) than a grab air sample taken to down-post the room from ARA status. Fixed head air samples are taken in occupied areas likely to exceed 2 percent of an ALI; therefore, the required MDC (averaged over the year) is 2 percent of a DAC.

\section{Sample Line Loss}

Sample lines should be avoided wherever possible for work place air monitoring. If sample lines are used for collecting airborne particulate, the lines should be as short as possible and should be made of a material not subject to significant static charge effects (e.g. grounded metal). However, up to several feet of flexible plastic tubing, such as tygon, may be used to connect the sampling line to the sample collector. Flexible plastic tubing should only be used in the vertical; or only in the horizontal position, when repositioning CAMs is not practical. The penetration of particles with an aerodynamic equivalent diameter of $10 \mu \mathrm{m}$ should be at least 50 percent.

\footnotetext{
${ }^{11}$ An example of applicable limits would be $10 \% \mathrm{DAC}$ for no respiratory protection, or $10 \mathrm{DAC}$ with a respiratory protection factor of 100 .
} 
DEPOSITION software should be used for calculating particle penetration where applicable ${ }^{12}$. Sample line loss evaluations may be found in engineering configuration document WHC-SD-CP-SDD-011.

More detailed information and guidance for design of sample lines may be obtained from NUREG 1400 and ANSI N13.1.

\section{Selection of Air Sample Filters}

Site approved sample filter media used for air sampling (applicable to PFP) are as follows:

- VERSAPORE 3000

This filter is recommended for most applications at PFP, such as FHAS, CAMs, and grab air sampling. This filter is rugged, and is suitable for destructive analysis.

\section{- FLUOROPORE FS}

This air sample filter is normally used for alpha spectrometry analysis. Because of the filters' higher resolution capabilities, it may be used for breathing air CAMs. Because of relatively high cost, these filters should not be used for fixed head air sampling or grab air sampling unless alpha spectrometry is needed for analysis. These filters may be used for all work place air monitoring applications. This filter is not appropriate for destructive analysis. Because of this, these filters shall not be used for stack monitoring CAMs or environmental air sampling ${ }^{13}$.

\section{Airflow Analysis}

The most current airflow analysis for the facility is dated $1991^{14}$. The PFP's Radiological Control Organization is currently evaluating each sampler location, and will provide a technical basis for each location at a later date. Detailed information and guidance for airflow analysis methods may be obtained from NUREG 1400.

\footnotetext{
${ }^{12}$ Contact Facility or Site Technical Authority for work place air monitoring for information regarding DEPOSITION software.

${ }^{13}$ Though environmental air sampling applications are not in the scope of this document; PFP radiological control normally performs sample-changing services for the facility, and should be aware of allowed filter types.

${ }^{14}$ See: "Evaluation of Workplace Air Monitoring Locations in Selected Areas of the Plutonium Finishing Plant," G.A. Stoetzel and G.R. Cicotte, May, 1991; Pacific Northwest Laboratory, Richland, WA
} 


\subsection{Tracking and Trending Program}

Work place air monitoring air samples are tracked through ABCASH. The PFP's air sample trending program may be found in FSP-PFP-5-8 volume 2, section 14.18, Trending Air Sample Data. This procedure outlines which air samples are to be trended for analysis. The procedure also establishes a basis for investigations of abnormal air sample data. 


\section{Required Air Monitoring at the PFP Complex}

This section describes the required air monitoring by building and room number. The information provided (in Table 4) is as follows:

- Building/Room Number

- Building number only if no source term exists

- Source Term Characterization

- Use Logic Codes for most categories

- $\mathrm{A}=$ Glovebox, source term disturbed (In-Service)

- $B=$ Fume Hood, source term disturbed (In-Service)

- $\mathrm{C}=$ Contamination $>880 \mathrm{dpm} / 100 \mathrm{~cm}^{2}, \leq 44.4 \mathrm{E} 3 \mathrm{dpm} / 100 \mathrm{~cm}^{2}$

- $\mathrm{D}=$ Glovebox, source term not disturbed (inactive ${ }^{15}$ or pie-plated to prevent use)

- $E=$ Fume Hood, source term not disturbed (inactive or sash down to prevent use)

- $\mathrm{F}=$ Vault items

- $\mathrm{G}=$ No source term (contamination less than $880 \mathrm{dpm} / 100 \mathrm{~cm}^{2}$, no Glovebox, fume hoods) or source term contained to prevent release (sealed sources, or source contained in piping)

- Occupancy Category

- Category I = Not Occupied (occupied for less than $96 \mathrm{~min} /$ day, $8 \mathrm{hrs} / \mathrm{wk}, 104$ hrs/quarter, or $416 \mathrm{hrs} / \mathrm{calendar}$ year - True Rate, not average)

- $\quad$ Category II = Infrequently Occupied (occupied for less than $2000 \mathrm{hrs} / \mathrm{yr}$.)

- Category III = Continuously Occupied (occupied for $2000 \mathrm{hrs} / \mathrm{yr}$.)

- Comments

Comments include data and historical information that may be used for exceptions from Table 3 and other recommendations.

- Required Air Monitoring

- CAMs, FHAS or None

- Assume fixed location air monitoring

- Comments will be given when non-fixed location air monitoring is appropriate

Information on all categories have been obtained from document review, observation and personnel interview. Information for work performed with source term and occupancy categories has been obtained from the PFP FSAR ${ }^{16}$ and appropriate management.

\footnotetext{
${ }^{15}$ Not intended to include gloveboxes that are inactive because gloves have failed. This also assumes that the glovebox has ventilation.

${ }^{16}$ Occupancy information marked with an asterisk (e.g. I*, II*, III*) has been obtained from Table 8-14 of the PFP FSAR.
} 
The following table is a matrix for decisions concerning air-monitoring coverage. This table is used as a general tool for decision, designed to match most situations at the PFP, and is not an absolute rule. Exceptions may be made and recorded in the comment section of Table 4.

Table 3

\begin{tabular}{|c|c|c|c|c|c|c|c|}
\hline \multicolumn{7}{|c|}{ Air Monitoring Decision Matrix } \\
\hline & \multicolumn{7}{c|}{ Source Term Classification } \\
\hline $\begin{array}{c}\text { Occupancy } \\
\text { Class }\end{array}$ & A & B & C & D & E & F & G \\
\hline I & NONE & NONE & NONE & NONE & NONE & CAM & NONE \\
\hline II & $\begin{array}{c}\text { CAM, } \\
\text { FHAS }\end{array}$ & $\begin{array}{l}\text { CAM, } \\
\text { FHAS }\end{array}$ & FHAS & FHAS & FHAS & CAM & NONE \\
\hline III & $\begin{array}{l}\text { CAM, } \\
\text { FHAS }\end{array}$ & $\begin{array}{l}\text { CAM, } \\
\text { FHAS }\end{array}$ & FHAS & FHAS & FHAS & CAM & NONE \\
\hline
\end{tabular}

Using information from Table 3 and direction from this technical basis; Table 4, which describes the air monitoring requirements by room ${ }^{17}$, is as follows:

Table 4

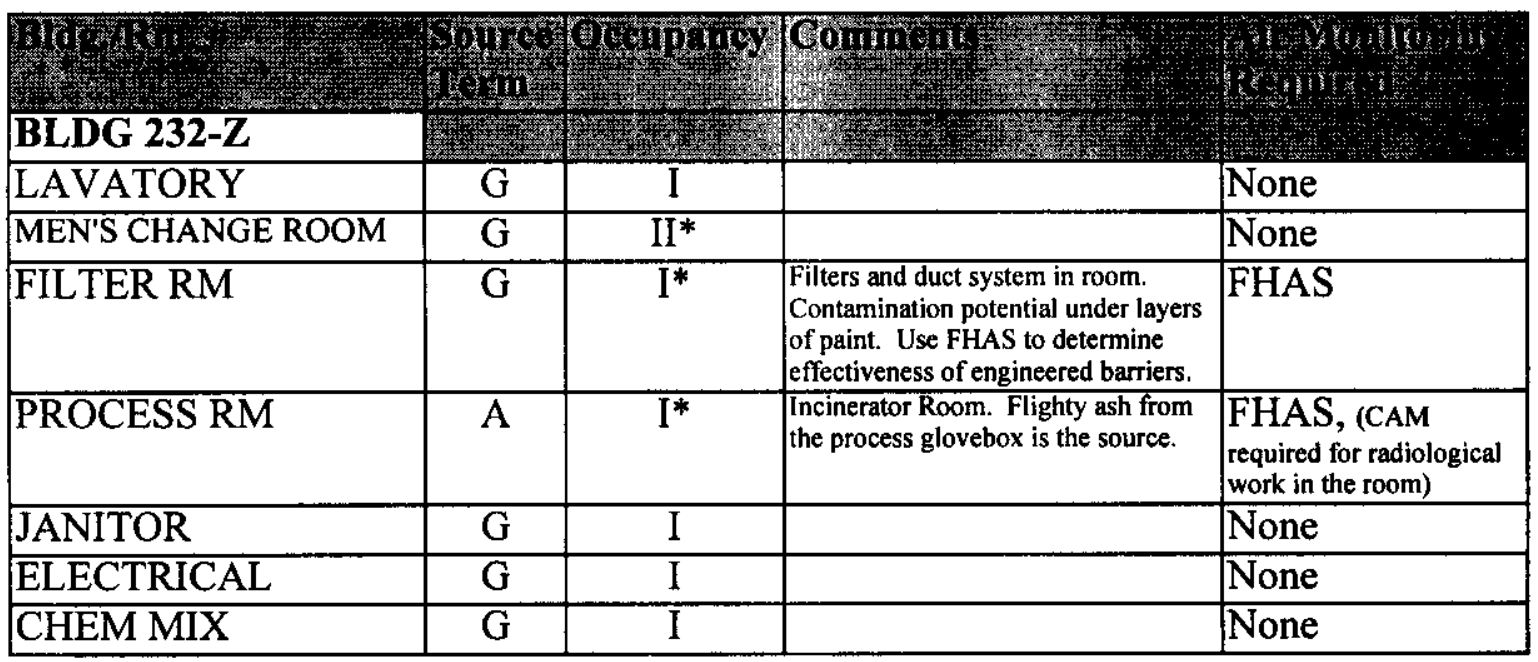

${ }^{17}$ Table 4 describes the air monitoring requirements of 10 CFR-835, HSRCM-1, HNF-PRO-331 and HNFSD-CP-SAR-021 for PFP. 


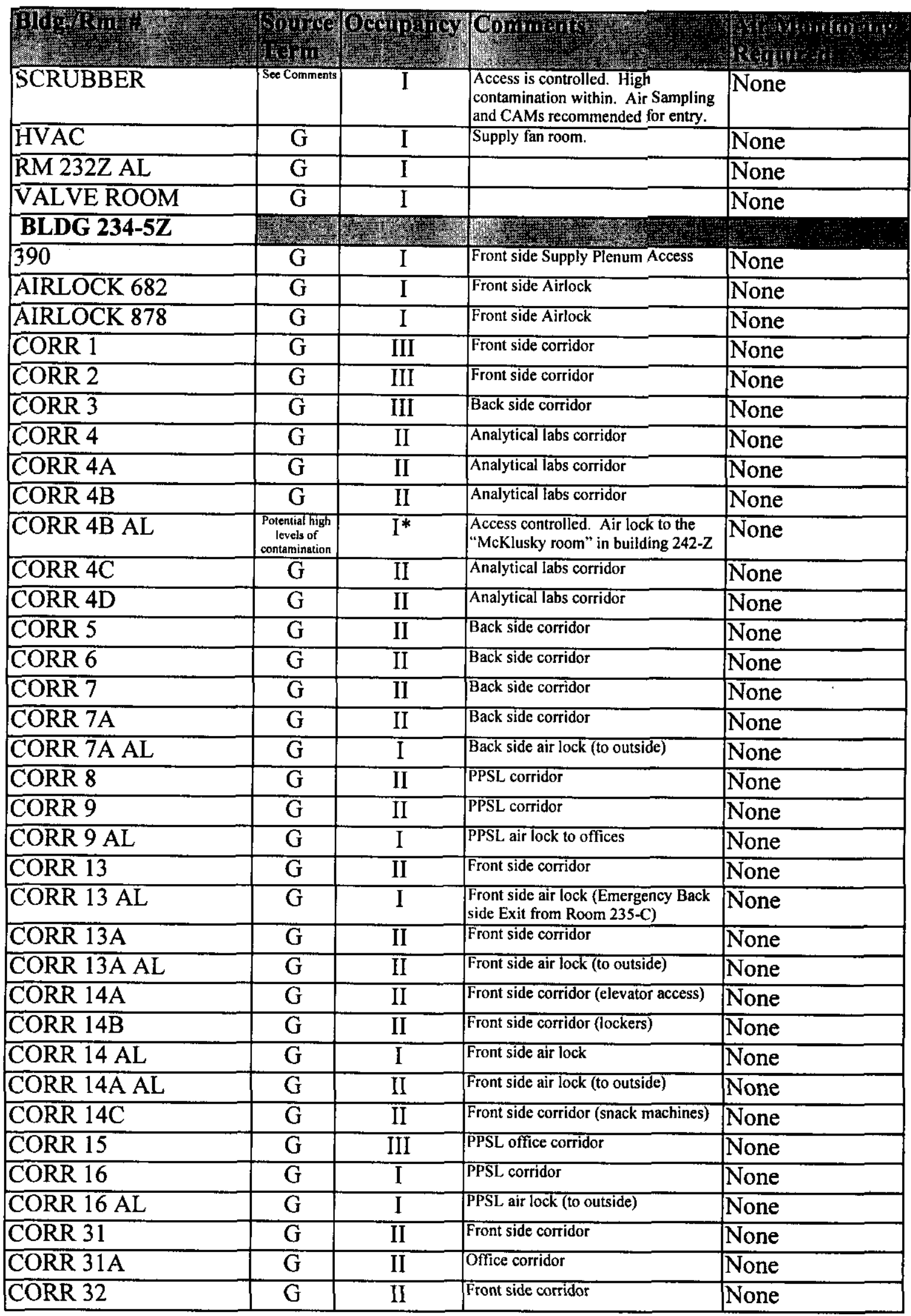




\begin{tabular}{|c|c|c|c|c|}
\hline 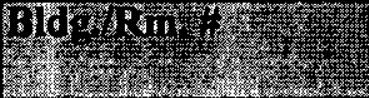 & 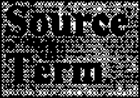 & Cor 10 & Comingur & Whangly \\
\hline CORR 33A & $\mathrm{G}$ & I & $\begin{array}{l}\text { Back side corridor (access to Fijter } \\
\text { Room 318) }\end{array}$ & None \\
\hline CORR 34 & $\mathrm{G}$ & $\bar{I}$ & $\begin{array}{l}\begin{array}{l}\text { Back side corridor (access to Filter } \\
\text { Rooms) }\end{array} \\
\end{array}$ & None \\
\hline CORR 192 & $\bar{G}$ & I & Back side corridor & None \\
\hline CORR $192 \mathrm{AL}$ & $\mathrm{G}$ & $\bar{I}$ & Back side air lock (to outside) & None \\
\hline CORR 242B & $\mathrm{G}$ & $\bar{I}$ & Bldg. $236 \mathrm{Z}$ main entry corridor & None \\
\hline CORR 242B AL & $\mathrm{G}$ & I & $\begin{array}{l}\text { Back side air lock (main back side } \\
\text { access) }\end{array}$ & None \\
\hline CORR 303-1 & $\mathrm{G}$ & II & Office corridor & None \\
\hline CORR 303-2 & $\mathrm{G}$ & $\mathrm{I}$ & Office storage & None \\
\hline GUARD STATION & $\bar{G}$ & III & $\begin{array}{l}\text { Guards stationed at backside primary } \\
\text { acess }\end{array}$ & None \\
\hline MEZZ 230A & See comments & I & $\begin{array}{l}\text { Within room 230A. Monitoring will } \\
\text { be the same as room } 230 \mathrm{~A} \text {. }\end{array}$ & See comments \\
\hline MEZZ 230B & See comments & I & $\begin{array}{l}\text { Within room } 230 \mathrm{~B} \text {. Monitoring will } \\
\text { be the same as room } 230 \mathrm{~B} \text {. }\end{array}$ & See comments \\
\hline MEZZ 230C & See comments & I & $\begin{array}{l}\text { Within room } 230 \mathrm{C} \text {. Monitoring will } \\
\text { be the same as room } 230 \mathrm{C} \text {. }\end{array}$ & Soe cormments \\
\hline MEZZ 235B & See comments & I & $\begin{array}{l}\text { Within room 235B. Monitoring will } \\
\text { be the same as room 235B. }\end{array}$ & See comments \\
\hline MEZZ 235D & \begin{tabular}{|l} 
See comments \\
\end{tabular} & I & $\begin{array}{l}\text { Within room 235D. Monitoring will } \\
\text { be the same as room 235D. }\end{array}$ & See comments \\
\hline MEZZ 236A & \begin{tabular}{|l|} 
See comments \\
\end{tabular} & I & $\begin{array}{l}\text { Within room 236A. Monitoring will } \\
\text { be the same as room 236A. }\end{array}$ & See comments \\
\hline MEZZ 236B & See comments & I & $\begin{array}{l}\text { Within room } 236 \mathrm{~B} \text {. Monitoring will } \\
\text { be the same as room } 236 \mathrm{~B} \text {. }\end{array}$ & See comments \\
\hline MEZZ 236C & See comments & I & $\begin{array}{l}\text { Within room } 235 \mathrm{C} \text {. Monitoring will } \\
\text { be the same as room } 236 \mathrm{C} \text {. }\end{array}$ & See comments \\
\hline$\overline{\mathrm{RM} 1}$ & $\bar{G}$ & I & $\begin{array}{l}\text { Within Tunnel } 1 \text {. Monitoring will be } \\
\text { the same as Tunnel } 1 \text {. }\end{array}$ & See comments \\
\hline$\overline{\text { RM } 2}$ & $\bar{G}$ & $\overline{\mathrm{I}}$ & $\begin{array}{l}\text { Within Tunnel } 6 \text {. Monitoring will be } \\
\text { the same as Tunnel } 6 \text {. }\end{array}$ & See comments \\
\hline RM 3 & $\bar{G}$ & I & $\begin{array}{l}\text { Within Tunnel } 4 \text {. Monitoring will be } \\
\text { the same as Tunnel } 4\end{array}$ & Soe comments \\
\hline RM 4 & $\mathrm{G}$ & I & Room adjacent to Tunnels 5 and 7 & None \\
\hline RM 5 & $\overline{\mathrm{G}}$ & I & Radioactive Waste Storage & None \\
\hline RM 80 & $\mathrm{G}$ & II & PPSL storage & None \\
\hline RM 81 & $\mathrm{G}$ & III & PPSL office & None \\
\hline$\overline{\text { RM } 82}$ & $\mathrm{G}$ & III & PPSL office & None \\
\hline RM 83 & $\mathrm{G}$ & III & PPSL office & None \\
\hline$\overline{\mathrm{RM}} 84$ & $\bar{G}$ & I & M. Restroom (PPSL) & None \\
\hline RM 85 & $\overline{\mathrm{G}}$ & I & W. Restroom (PPSL) & None \\
\hline RM 86 & $\mathrm{G}$ & III & PPSL office & None \\
\hline RM 87 & $\mathrm{G}$ & III & PPSL office & None \\
\hline RM 88 & $\mathrm{G}$ & III & PPSL office & None \\
\hline RM 89 & $\mathrm{G}$ & III & PPSL office & None \\
\hline RM 90 & $\mathrm{G}$ & III & PPSL office & None \\
\hline RM 92 & $\mathrm{G}$ & I & PPSL hot water closet & None \\
\hline RM 100 & $\mathrm{G}$ & III & Front side main foyer & None \\
\hline RM 101 & $\bar{G}$ & III & Front side office & None \\
\hline RM 102 & $\bar{G}$ & $\overline{\text { III }}$ & Front side office & None \\
\hline
\end{tabular}




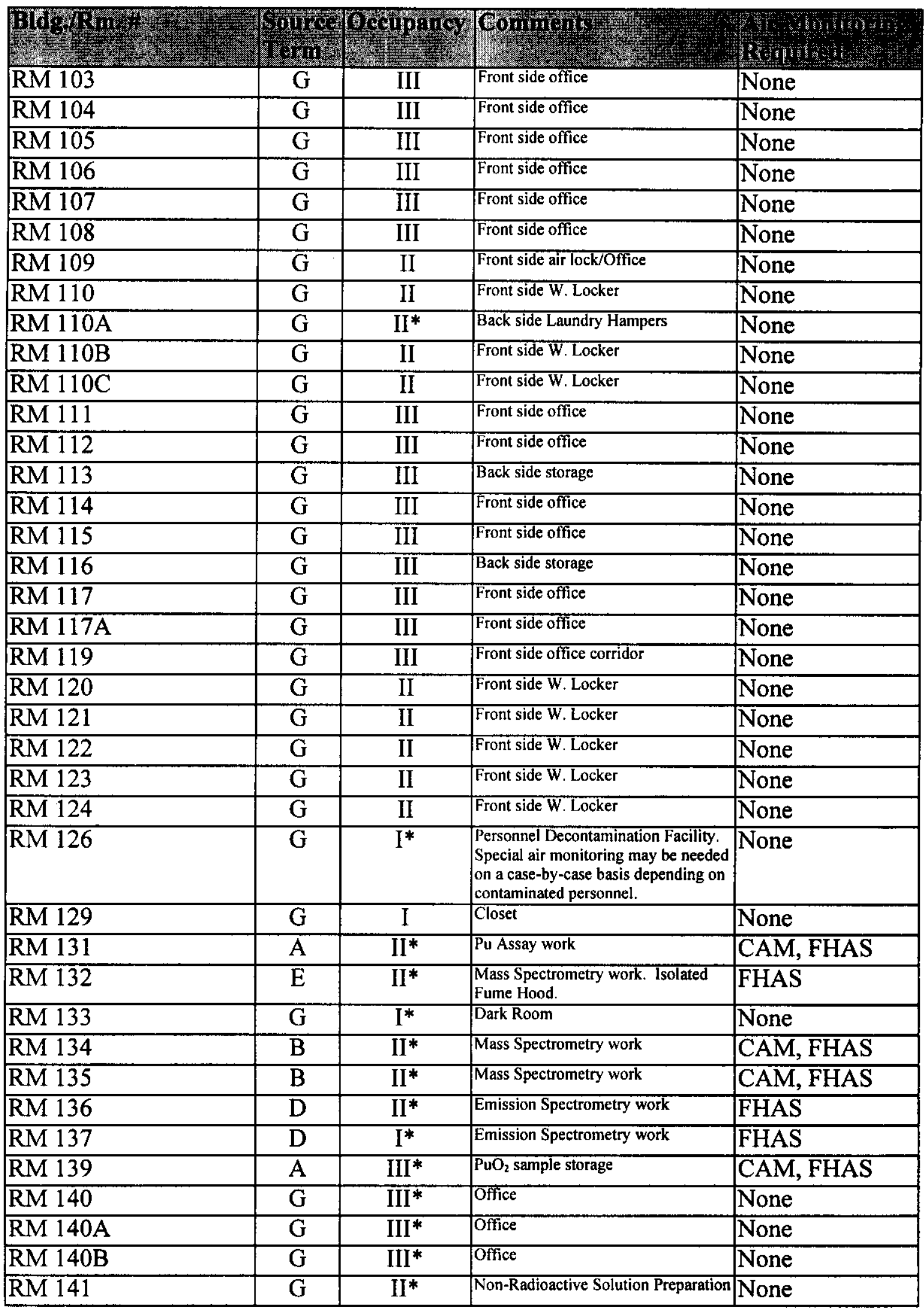




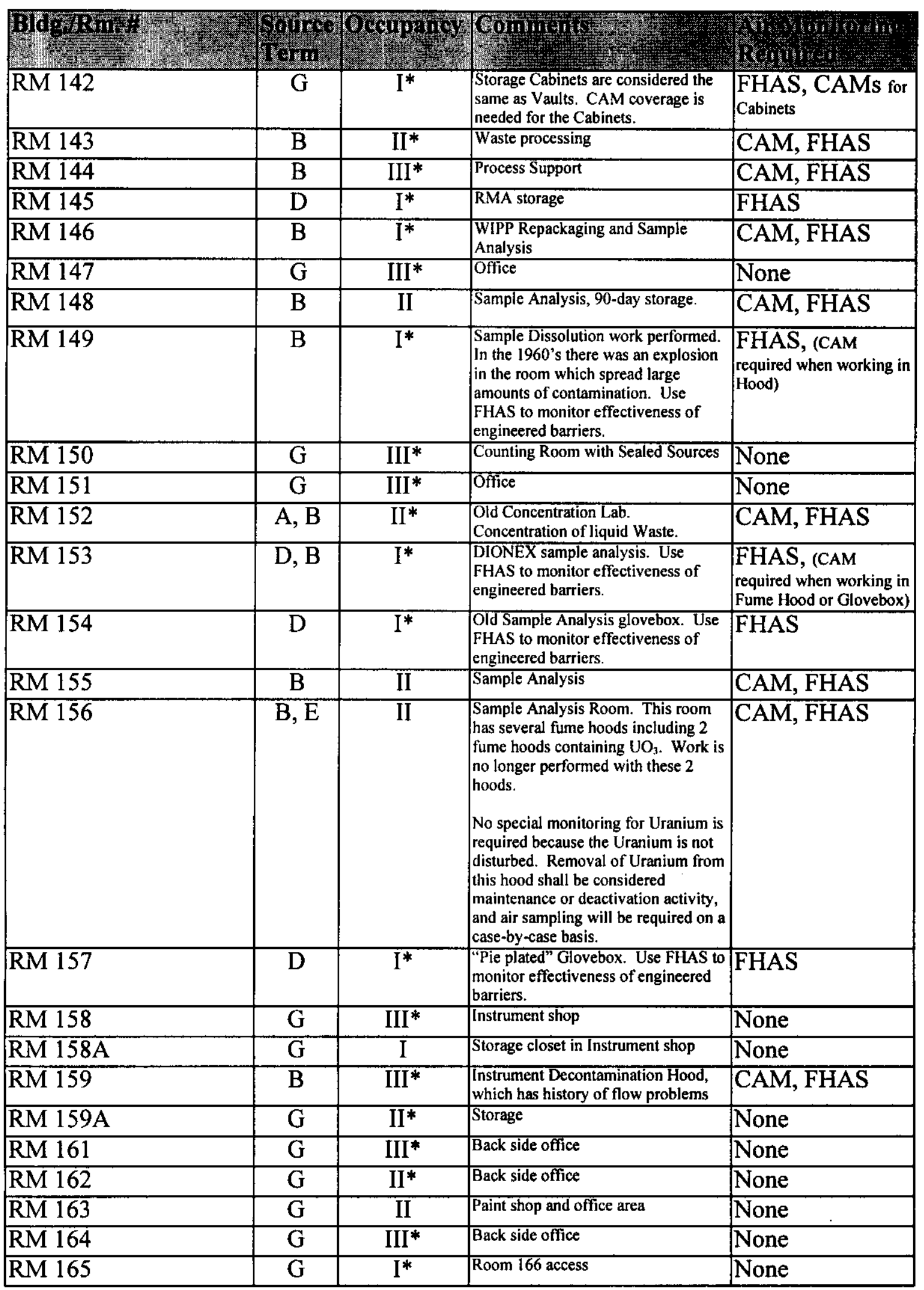




\begin{tabular}{|c|c|c|c|c|}
\hline 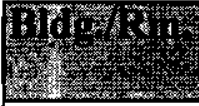 & Promer & Hopnoy & Comirionir & 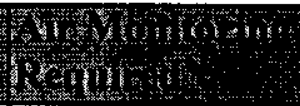 \\
\hline RM 166 & $\mathrm{~A}, \mathrm{~B}$ & $I^{*}$ & $\begin{array}{l}\text { Primarily drum storage for Solid } \\
\text { Waste Operations. Contains fume } \\
\text { hood and gloveboxes. Historical } \\
\text { evidence shows potential for leaking } \\
\text { from engineered barriers in room. }\end{array}$ & $\begin{array}{l}\text { FHAS, (CAM } \\
\text { required for radiological } \\
\text { work in room) }\end{array}$ \\
\hline RM 167 & $\overline{\mathrm{G}}$ & III* & PPE Change room & None \\
\hline RM 168 & $\mathrm{G}$ & III* & PPE Change room & None \\
\hline RM 169 & $\mathrm{D}$ & $I^{*}$ & $\begin{array}{l}\text { "Pie plated" Glovebox. Use FHAS to } \\
\text { monitor the effectiveness of } \\
\text { Engineered Barriers. }\end{array}$ & FHAS \\
\hline RM 170 & $\mathrm{D}, \mathrm{E}$ & $I^{*}$ & $\begin{array}{l}\text { "Pie plated" Glovebox and Hood with } \\
\text { sash down. Use FHAS to monitor the } \\
\text { effectiveness of Engineered Barriers. }\end{array}$ & FHAS \\
\hline RM 171 & $\mathrm{G}$ & III* & Corridor, drum storage & None \\
\hline $\mathrm{RM} 172$ & $\mathrm{G}$ & $I^{*}$ & $\begin{array}{l}\text { Item storage. Use FHAS to monitor } \\
\text { effectiveness of engineered barrier }\end{array}$ & FHAS \\
\hline RM 173 & $\mathrm{G}$ & $\mathrm{I}^{*}$ & Equipment storage for Rm 192 & None \\
\hline RM 174 & $\bar{F}$ & $I^{*}$ & Vault & CAM \\
\hline RM 175 & $\mathrm{~F}$ & $\mathrm{I}^{*}$ & Vault & CAM \\
\hline $\mathrm{RM} 176$ & $\bar{G}$ & $\mathrm{I}$ & Air lock & None \\
\hline RM 179 & $\bar{A}$ & III* & Process Support Laboratory & CAM, FHAS \\
\hline RM 180 & $\mathrm{G}$ & $\mathrm{II}^{*}$ & $\begin{array}{l}\text { Thermal analysis lab (hood in room } \\
\text { not contaminated at this time) }\end{array}$ & None \\
\hline $\mathrm{RM} 182$ & $\mathrm{G}$ & $\mathrm{II}^{*}$ & Scanning electron microscope & None \\
\hline RM 183 & $\mathrm{G}$ & $\mathrm{II}^{*}$ & Drum/chemical storage & None \\
\hline RM 185 & $\mathrm{G}$ & $I^{*}$ & Drum/chemical storage & None \\
\hline RM 186 & $\bar{G}$ & I & Seismic shutdown switch room & None \\
\hline RM 187 & $\overline{\mathrm{B}}$ & III* & Process development & CAM, FHAS \\
\hline RM 188 & $\mathrm{~A}$ & III* & Prototype De-nitration Caliciner & CAM, FHÁS \\
\hline RM 189 & $\mathrm{G}$ & II* & Ion chromatography & None \\
\hline RM 190 & $\mathrm{~F}$ & $I^{*}$ & Vault & CAM \\
\hline RM 191 & $\mathrm{G}$ & $\mathrm{II}^{*}$ & Non-radioactive chemistry & None \\
\hline RM 192 & $\mathrm{G}$ & II* & $\begin{array}{l}\text { Radioactive material storage/assay } \\
\text { room }\end{array}$ & None \\
\hline RM 192A & $\bar{F}$ & $I^{*}$ & $\begin{array}{l}\text { Un-irradiated fuel storage vauft. Also } \\
\text { contains some stored MOX items. } \\
\text { Creation of airborne radioactive } \\
\text { material is highly unlikely }\end{array}$ & None \\
\hline RM 192B & $\mathrm{F}$ & $I^{*}$ & Vault & CAM \\
\hline RM 192C & $\bar{F}$ & $I^{*}$ & Vault & $\overline{\mathrm{CAM}}$ \\
\hline RM 192D & $\bar{G}$ & $I^{*}$ & $\begin{array}{l}\text { Drum storage (items and old L-10). } \\
\text { Use FHAs to monitor the } \\
\text { effectiveness of engineered barriers. }\end{array}$ & FHAS \\
\hline RM 192N & $\mathrm{G}$ & I & Back side Office & None \\
\hline RM 192S & $\bar{G}$ & $I^{*}$ & Back side Office & None \\
\hline RM 193 & $\bar{G}$ & $I^{*}$ & Airlock & None \\
\hline RM 194 & $\bar{G}$ & $I$ & Front side tool storage & None \\
\hline RM 194A & $\mathrm{G}$ & II & Front side tool storage & None \\
\hline RM 194B & $\bar{G}$ & III & Front side office & None \\
\hline RM 195M & $\mathrm{G}$ & $\mathrm{I}$ & M. Rest room (inactive) & None \\
\hline
\end{tabular}




\begin{tabular}{|c|c|c|c|c|}
\hline Blogramy & Sing & Oaciplaty & Coniminis & Rrun \\
\hline RM 195W & $\overline{\mathrm{G}}$ & $\bar{I}$ & W. Restroom (inactive) & None \\
\hline RM 196 & $\mathrm{G}$ & $I^{*}$ & 90 Day storage area & None \\
\hline RM 197 & $\bar{G}$ & $\mathrm{I}^{*}$ & $\begin{array}{l}\text { Drum storage (Items and old L-10). } \\
\text { Use FHAs to monitor the } \\
\text { effectivenss of engineered barriers. }\end{array}$ & FHAS \\
\hline RM 197A & $\overline{\mathrm{G}}$ & $\mathrm{I}$ & Mixed Waste: 90 day storage. & None \\
\hline RM 198 & $\bar{G}$ & $\overline{\mathrm{III}}$ & Front side machine shop & None \\
\hline $\mathrm{RM} 198 \mathrm{AL}$ & $\mathrm{G}$ & $\bar{I}$ & \begin{tabular}{|l|} 
Front side airlock \\
\end{tabular} & None \\
\hline RM 198A & $\overline{\mathrm{G}}$ & $\overline{\mathrm{III}}$ & Lunch Room & None \\
\hline RM 199 & $\mathrm{G}$ & II & Front side weld shop & None \\
\hline RM 200 & $\bar{G}$ & $\mathrm{I}$ & Front side machinery storage & None \\
\hline RM 200A & $\bar{G}$ & $\bar{I}$ & Front side machinery storage & None \\
\hline RM 201 & $\mathrm{G}$ & $I$ & Front side storage & None \\
\hline RM 202 & $\mathrm{G}$ & II & Front side "cold" development lab & None \\
\hline RM 205 & $\bar{G}$ & III & Front side office & None \\
\hline RM 208 & $\bar{G}$ & II & Front side copy room & None \\
\hline RM 208A & $\bar{G}$ & $\bar{I}$ & Front side office/closet & None \\
\hline RM 209 & $\bar{G}$ & $\overline{\text { III }}$ & Front side office & None \\
\hline RM 210 & $\bar{G}$ & III & Front side office & None \\
\hline RM211 & $\bar{G}$ & III & Front side office & None \\
\hline RM 212 & $\bar{G}$ & III & Front side office & None \\
\hline RM 212A & $\mathrm{G}$ & I & \begin{tabular}{|l} 
Front side office storage \\
\end{tabular} & None \\
\hline RM 214 & $\overline{\mathrm{G}}$ & I & Front side office storage & None \\
\hline RM 215 & $\mathrm{G}$ & III & Front side office & None \\
\hline RM 216 & $\bar{G}$ & $\mathrm{I}$ & Front side office storage & None \\
\hline RM 217 & $\bar{G}$ & III & Front side office & None \\
\hline RM 217A & $\bar{G}$ & $\overline{\text { III }}$ & Front side office & None \\
\hline RM 218A & $\mathrm{G}$ & III & Front side office & None \\
\hline RM 218B & $\mathrm{G}$ & III & Front side office & None \\
\hline RM 218C & $\bar{G}$ & III & Front side office & None \\
\hline RM 218D & $\bar{G}$ & III & Front side office & None \\
\hline RM 218E & $\bar{G}$ & $\overline{\text { III }}$ & Front side office & None \\
\hline $\mathrm{RM} 218 \mathrm{~F}$ & $\mathrm{G}$ & $\overline{\text { III }}$ & Front side office & None \\
\hline RM 221A & $\bar{G}$ & III* & HPT Office/Counting Equipment & None \\
\hline RM 221B & $\mathrm{G}$ & III* & HPT Instrument and Source Storage & None \\
\hline RM 221C & $A, B$ & II $^{*}$ & Standards Lab & CAM, FHAS \\
\hline RM 221D & $\mathrm{A}, \mathrm{B}$ & II* & Standards Lab & CAM, FHAS \\
\hline $\mathrm{RM} 221 \mathrm{E}$ & $\mathrm{B}$ & $\mathrm{II}^{*}$ & \begin{tabular}{|l} 
Standards Lab \\
\end{tabular} & CAM, FHAS \\
\hline RM 221F & $\bar{G}$ & III & \begin{tabular}{|l} 
RC Supervisor Office \\
\end{tabular} & None \\
\hline RM 221G & $\bar{G}$ & III & \begin{tabular}{l|} 
A-Labs air sample counting room \\
(Tennelec)
\end{tabular} & None \\
\hline RM 223 & $\bar{G}$ & I & W. Shower & None \\
\hline RM 224 & $\mathrm{G}$ & $\mathrm{I}$ & Back side passageway & None \\
\hline RM 225 & $\mathrm{F}$ & $\mathrm{I}^{*}$ & Vault & CAM \\
\hline
\end{tabular}




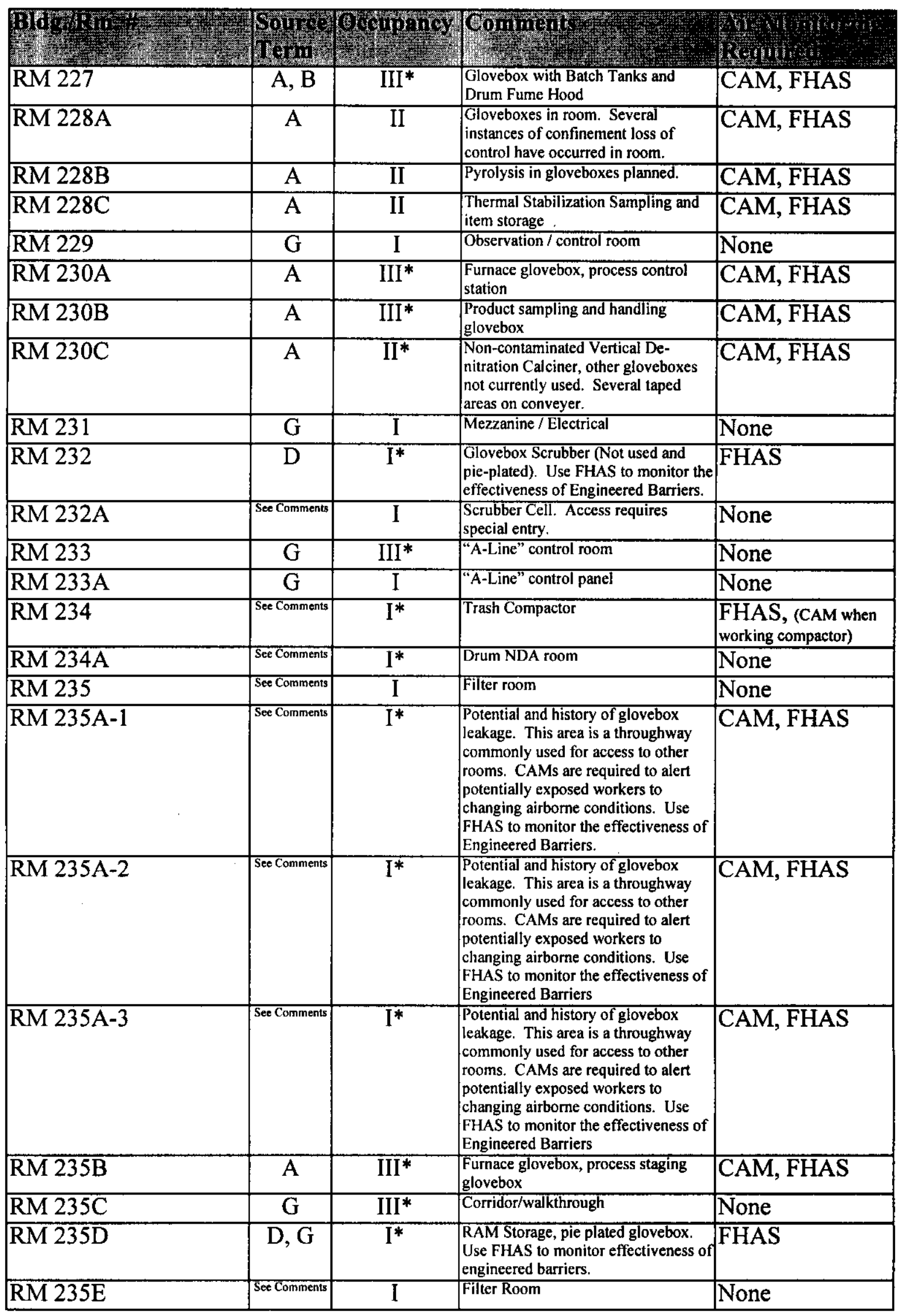




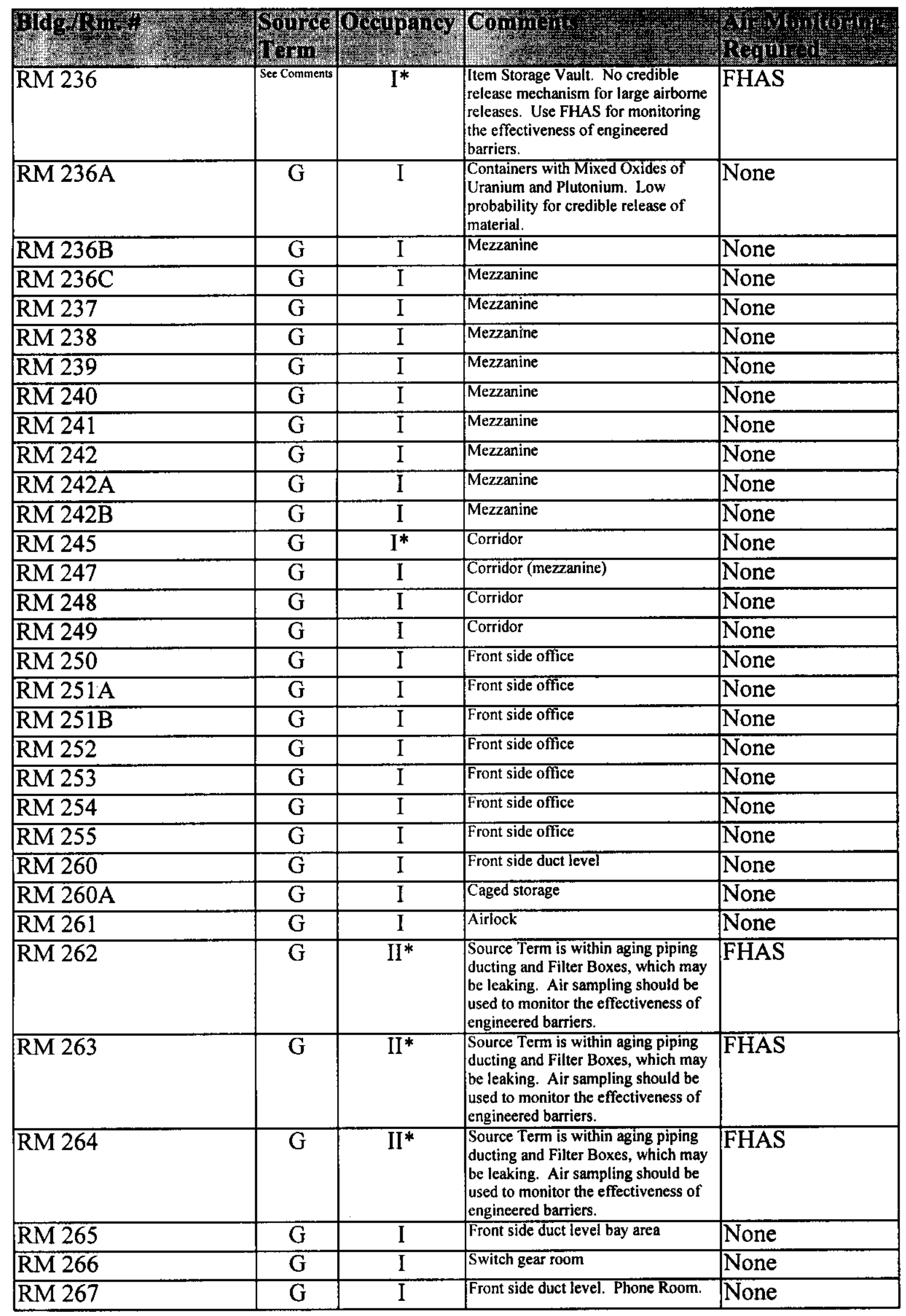




\begin{tabular}{|c|c|c|c|c|}
\hline Blowaring & 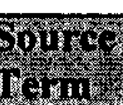 & Cocuparcy & Commentis & Rerines \\
\hline RM 268 & $\mathrm{G}$ & $\mathrm{I}$ & Front side duct level. Storage Room. & None \\
\hline RM 269 & $\mathrm{G}$ & I & Front side duct level. Battery Room. & None \\
\hline RM 270 & $\bar{G}$ & I & Front side storage & None \\
\hline RM 270A & $\mathrm{G}$ & $\bar{I}$ & Air lock & None \\
\hline RM 271 & $\overline{\mathrm{G}}$ & $\bar{I}$ & PRF Supply damper room & None \\
\hline RM 272 & $\bar{G}$ & $\bar{I}$ & \begin{tabular}{|l|} 
Front side duct level. \\
\end{tabular} & None \\
\hline RM 300 & $\bar{G}$ & $\overline{\text { II }}$ & Front side bay area storage & None \\
\hline RM 301 & $\mathrm{G}$ & III & Front side office & None \\
\hline$\overline{R M} 301 \mathrm{~A}$ & $\mathbf{G}$ & III & Front side office & None \\
\hline RM 301B & $\mathrm{G}$ & IIII & Front side office & None \\
\hline RM 301C & $\bar{G}$ & III & Front side office & None \\
\hline RM 301D & $\mathrm{G}$ & III & Front side office & None \\
\hline RM 302 & $\bar{G}$ & I & Mock-up area & None \\
\hline RM 303 & $\bar{G}$ & $\overline{\mathrm{III}}$ & Front side office & None \\
\hline $\mathrm{RM} 303 \mathrm{~A}$ & $\mathrm{G}$ & III & Front side office & None \\
\hline RM 303B & $\mathrm{G}$ & III & Front side office & None \\
\hline RM 303C & $\overline{\mathrm{G}}$ & $\overline{\text { III }}$ & Front side office & None \\
\hline RM 303D & $\overline{\mathrm{G}}$ & $\overline{\text { III }}$ & Front side office & None \\
\hline RM 303E & $\overline{\mathrm{G}}$ & III & Front side office & None \\
\hline RM 303F & $\bar{G}$ & III & Front side office & None \\
\hline RM 303G & $G$ & III & Front side office & None \\
\hline $\mathrm{RM} 303 \mathrm{H}$ & $\overline{\mathrm{G}}$ & III & \begin{tabular}{|l} 
Front side office \\
\end{tabular} & None \\
\hline RM 303J & $\mathrm{G}$ & III & Front side office & None \\
\hline RM 303K & $\bar{G}$ & III & Front side office storage & None \\
\hline RM 303L & $\mathrm{G}$ & III & Front side office & None \\
\hline RM 303M & $\bar{G}$ & $\overline{\text { III }}$ & Front side office & None \\
\hline RM 304 & $\overline{\mathrm{G}}$ & III & \begin{tabular}{|l|l|l|l} 
Plastic shop \\
\end{tabular} & None \\
\hline RM 304A & $\bar{G}$ & III & Front side office & None \\
\hline RM 304B & $\mathrm{G}$ & III & Front side office & None \\
\hline RM 305 & $\mathbf{G}$ & III & Lunch room & None \\
\hline RM 305A & $\bar{G}$ & I & Closet & None \\
\hline RM 306 & $\mathrm{G}$ & II & Conference room & None \\
\hline RM 306A & $\mathrm{G}$ & II & Computer room & None \\
\hline RM 307 & $\bar{G}$ & $\bar{I}$ & Air lock & None \\
\hline $\mathrm{RM} 308$ & $\mathrm{G}, \mathrm{C}$ & $\overline{I I}^{*}$ & $\begin{array}{l}\text { Source Term is within aging piping } \\
\text { ducting and Filter Boxes, which may } \\
\text { be leaking. Air sampling should be } \\
\text { used to monitor the effectiveness of } \\
\text { engineered barriers. High } \\
\text { Contamination Area is posted, but } \\
\text { under ducting (difficult to } \\
\text { unintentionally disturb) and not } \\
\text { disturbed. CAMs and Grab Air } \\
\text { Sampling is recommended when High } \\
\text { CA surfaces are disturbed. }\end{array}$ & FHAS \\
\hline
\end{tabular}




\begin{tabular}{|c|c|c|c|c|}
\hline Bog/ming & $\begin{array}{l}\text { Wounce } \\
\text { Tomin }\end{array}$ & (6) & Comments & 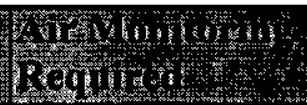 \\
\hline RM 309 & $\begin{array}{l}\text { Potential for } \\
\text { High levels of } \\
\text { contamination }\end{array}$ & $I^{*}$ & $\begin{array}{l}\text { E-4 filter room. Entry requires special } \\
\text { access control. Draws air from } \\
\text { gloveboxes and hoods. CAMs and } \\
\text { Grab Air Sampling recommended for } \\
\text { entry. }\end{array}$ & None \\
\hline RM 310 & $\begin{array}{c}\text { Potential for } \\
\text { High levels of } \\
\text { contaminstion }\end{array}$ & $I^{*}$ & $\begin{array}{l}\text { E-4 filter room. Entry requires special } \\
\text { access control. Draws air from } \\
\text { gloveboxes and hoods. CAMs and } \\
\text { Grab Air Sampling recommended for } \\
\text { entry. }\end{array}$ & None \\
\hline RM 311 & \begin{tabular}{|c|} 
Potential for \\
High levels of \\
contamination
\end{tabular} & $\mathrm{I}^{*}$ & $\begin{array}{l}\text { E-3 filter room. Entry requires special } \\
\text { access control. Draws air from } \\
\text { breathing air spaces. CAMs and Grab } \\
\text { Air Sampling recommended for entry. }\end{array}$ & None \\
\hline RM 312 & \begin{tabular}{|c|} 
Potential for \\
High levels of \\
contamination
\end{tabular} & $I^{*}$ & $\begin{array}{l}\text { E-3 filter room. Entry requires special } \\
\text { access control. Draws air from } \\
\text { breathing air spaces. CAMs and Grab } \\
\text { Air Sampling recommended for entry. }\end{array}$ & None \\
\hline RM 313 & \begin{tabular}{|c|} 
Potential for \\
High levels of \\
contamination
\end{tabular} & $\mathrm{I}^{*}$ & $\begin{array}{l}\text { E-3 filter room. Entry requires special } \\
\text { access control. Draws air from } \\
\text { breathing air spaces. CAMs and Grab } \\
\text { Air Sampling recommended for entry. }\end{array}$ & None \\
\hline$\overline{\mathrm{RM} 314}$ & \begin{tabular}{|c|} 
Potential for \\
High levels of \\
contamination
\end{tabular} & $I^{*}$ & $\begin{array}{l}\text { E-3 filter room. Entry requires special } \\
\text { access control. Draws air from } \\
\text { breathing air spaces. CAMs and Grab } \\
\text { Air Sampling recommended for entry. }\end{array}$ & None \\
\hline RM 315 & \begin{tabular}{|c|}
$\begin{array}{c}\text { Potential for } \\
\text { High levels of } \\
\text { contamination }\end{array}$ \\
\end{tabular} & $I^{*}$ & $\begin{array}{l}\text { E-3 filter room. Entry requires special } \\
\text { access control. Draws air from } \\
\text { breathing air spaces. CAMs and Grab } \\
\text { Air Sampling recommended for entry. }\end{array}$ & None \\
\hline$\overline{\text { RM } 316}$ & \begin{tabular}{|l|} 
Poternitial or \\
High levels of \\
contamination
\end{tabular} & $\mathrm{I}^{*}$ & $\begin{array}{l}\text { E-3 filter room. Entry requires special } \\
\text { access control. Draws air from } \\
\text { breathing air spaces. CAMs and Grab } \\
\text { Air Sampling recommended for entry. }\end{array}$ & None \\
\hline RM 318 & 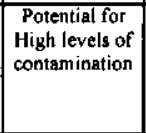 & $I^{*}$ & $\begin{array}{l}\text { E-3 filter room. Entry requires special } \\
\text { access control. Draws air from } \\
\text { breathing air spaces. CAMs and Grab } \\
\text { Air Sampling recommended for entry. }\end{array}$ & None \\
\hline RM 319 & $\mathrm{G}$ & I & Air lock. & None \\
\hline RM 320 & $\bar{G}$ & $I^{*}$ & $\begin{array}{l}\text { Source Term is within aging piping } \\
\text { ducting and Filter Boxes, which may } \\
\text { be leaking. Use FHAS to monitor the } \\
\text { effectiveness of engineered barriers. }\end{array}$ & FHAS \\
\hline RM 321 & $\mathrm{G}$ & I & Power operations room & None \\
\hline$\overline{\mathrm{RM}} 321 \mathrm{~A}$ & $\bar{G}$ & II & Control room & None \\
\hline RM 321B & $\bar{G}$ & II & Change room. & None \\
\hline RM 321C & $\overline{\mathrm{G}}$ & II & Office & None \\
\hline RM 322 & $\bar{G}$ & II & Electrical shop & None \\
\hline RM 323 & $\overline{\mathrm{G}}$ & II & Electrical shop & None \\
\hline RM 324 & $\mathrm{G}$ & $\bar{I}$ & Janitor Closet & None \\
\hline RM 325 & $\bar{G}$ & II & Electrical shop & None \\
\hline RM 326 & $\overline{\mathrm{G}}$ & $\mathrm{I}$ & Air lock & None \\
\hline RM 327 & $\mathrm{G}$ & $\mathrm{I}$ & M. Locker & None \\
\hline RM 329 & $\bar{G}$ & II & M. Rest room & None \\
\hline RM 330 & $\overline{\mathrm{G}}$ & I & M. Shower & None \\
\hline RM 331 & $\bar{G}$ & I & Closet & None \\
\hline RM 332 & $\overline{\mathrm{G}}$ & $\mathrm{I}$ & Locker room access & None \\
\hline
\end{tabular}




\begin{tabular}{|c|c|c|c|c|}
\hline 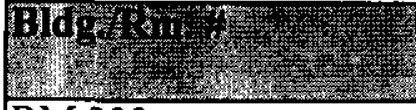 & Wolnow & Crotipary & Cominents & 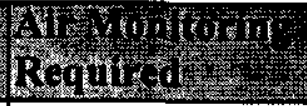 \\
\hline RM 333 & $\mathrm{G}$ & II & M. Rest room & None \\
\hline RM 333A & $\mathrm{G}$ & II & W. Rest room & None \\
\hline RM 334 & $\bar{G}$ & $\mathrm{I}$ & Storage room & None \\
\hline RM 335 & $\mathrm{G}$ & I & Storage room & None \\
\hline RM 336 & $\mathrm{G}$ & I & Chemical make-up & None \\
\hline RM 337 & $\mathrm{G}$ & $\overline{\mathrm{I}}$ & Chemical make-up & None \\
\hline RM 338 & $\bar{G}$ & I & Storage & None \\
\hline RM 340 & $\mathrm{G}$ & I & Instrument shop & None \\
\hline RM 341 & $\mathrm{G}$ & $\mathrm{I}$ & Office & None \\
\hline RM 349 & $\mathrm{G}$ & III & Office & None \\
\hline RM 350 & $\bar{G}$ & I & $\begin{array}{l}\text { Backside corridor. Supply ducting } \\
\text { within room. }\end{array}$ & None \\
\hline RM 351 & $\bar{G}$ & II & Computer Equipment & None \\
\hline RM 734 & $\mathrm{G}$ & I & W. Change room closet & None \\
\hline RM $879 \mathrm{AL}$ & $\mathrm{G}$ & $\mathrm{I}$ & Front side air lock & None \\
\hline STR 1 & $\mathrm{G}$ & $\mathrm{I}$ & Stairwell & None \\
\hline STR 2 & $\bar{G}$ & I & Stairwell & None \\
\hline STR 3 & $G$ & I & Stairwell & None \\
\hline STR 4 & $\bar{G}$ & I & $\begin{array}{l}\begin{array}{l}\text { Stairwell. RAM storage under } \\
\text { stairwell. }\end{array} \\
\end{array}$ & None \\
\hline STR 5 & $\bar{G}$ & I & Stairwell & None \\
\hline STR 6 & $\bar{G}$ & I & Stairwell & None \\
\hline \begin{tabular}{|l} 
STR 12 \\
\end{tabular} & $\bar{G}$ & I & Stairwell & None \\
\hline STR 13 & $\bar{G}$ & I & Stairwell & None \\
\hline STR 14 & $\bar{G}$ & I & Stairwell & None \\
\hline STR 15 & $\mathrm{G}$ & I & Stairwell & None \\
\hline STR 16 & $\bar{G}$ & $\overline{\mathrm{I}}$ & Stairwell & None \\
\hline STR $17 \mathrm{~N}$ & $\mathrm{G}$ & I & Stairwell & None \\
\hline STR 17S & $\mathrm{G}$ & I & Stairwell & None \\
\hline STR 18 & $\mathrm{G}$ & $\mathrm{I}$ & Stairwell & None \\
\hline STR 19 & $\mathrm{G}$ & $\mathrm{I}$ & Stairwell & None \\
\hline STR 19 & $\bar{G}$ & I & Stairwell & None \\
\hline STR 20 & $\bar{G}$ & I & Stairwell & None \\
\hline STR 21 & $\bar{G}$ & I & Stairwell & None \\
\hline STR 23 & $\mathrm{G}$ & I & Stairwell & None \\
\hline STR 25 & $\mathrm{G}$ & I & Stairwell & None \\
\hline STR 26 & $\bar{G}$ & I & Stairwell & None \\
\hline STR 104 & $\bar{G}$ & I & Stairwell & None \\
\hline STR 105 & $\mathrm{G}$ & I & Stairwell & None \\
\hline STR 130 & $\mathrm{G}$ & I & Stairwell & None \\
\hline STR 134 & $\mathrm{G}$ & I & Stairwell & None \\
\hline STR 192B & $\mathrm{G}$ & I & Stairwell & None \\
\hline STR 192C & $\mathrm{G}$ & I & Stairwell & None \\
\hline
\end{tabular}




\begin{tabular}{|c|c|c|c|c|}
\hline 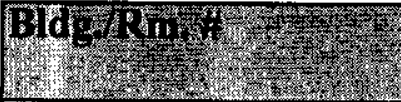 & 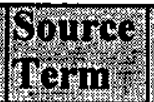 & 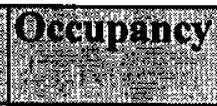 & Comin, & Hodnum \\
\hline STR 202 & $\mathrm{G}$ & I & Stairwell & None \\
\hline STR 228A & $\bar{G}$ & I & Stairwell & None \\
\hline STR 230B & $\bar{G}$ & $\overline{\mathrm{I}}$ & Stairwell & None \\
\hline STR 232N & $\bar{G}$ & I & Stairwell & None \\
\hline STR 235 & $\bar{G}$ & I & Stairwell & None \\
\hline STR 580 & $\bar{G}$ & I & Stairwell & None \\
\hline STR 633 & $\bar{G}$ & I & Stairwell & None \\
\hline STR 679 & $\overline{\mathrm{G}}$ & I & Stairwell & None \\
\hline STR 707 & $\bar{G}$ & I & Stairwell & None \\
\hline STR ROOF 1 & $\bar{G}$ & $\overline{\mathrm{I}}$ & \begin{tabular}{|l} 
Stairwell \\
\end{tabular} & None \\
\hline STR ROOF 2 & $\bar{G}$ & I & Stairwell & None \\
\hline STR ROOF 3 & $\mathrm{G}$ & I & Stairwell & None \\
\hline SUPPLY PLENUM CHAMBER & $\mathrm{G}$ & $\bar{I}$ & & None \\
\hline TUNNEL 1 & G & $\mathrm{I}$ & $\begin{array}{l}\text { Source term within piping. Use } \\
\text { FHAS to monitor the effectiveness of } \\
\text { engineered barriers. }\end{array}$ & FHAS \\
\hline TUNNEL 2 & $\bar{G}$ & I & $\begin{array}{l}\text { Source term within piping. Use } \\
\text { FHAS to monitor the effectiveness of } \\
\text { engineered barriers. }\end{array}$ & FHAS \\
\hline TUNNEL 3 & $\bar{G}$ & $\mathrm{I}$ & $\begin{array}{l}\text { Historically leaking flanges from } \\
\text { contaminated piping which have been } \\
\text { covered with wrapping. Use FHAS to } \\
\text { monitor the effectiveness of } \\
\text { engineered barriers. }\end{array}$ & FHAS \\
\hline TUNNEL 4 & $\overline{\mathrm{G}}$ & I & $\begin{array}{l}\text { Source term within piping. Use } \\
\text { FHAS to monitor the effectiveness of } \\
\text { engineered barriers. }\end{array}$ & FHAS \\
\hline TUNNEL 5 & $\overline{\mathrm{G}}$ & $\bar{I}$ & $\begin{array}{l}\text { Source term within piping. Use } \\
\text { FHAS to monitor the effectiveness of } \\
\text { engineered barriers. }\end{array}$ & FHAS \\
\hline TUNNEL 6 & $\overline{\mathrm{G}}$ & $\bar{I}$ & $\begin{array}{l}\text { Source term within piping. Use } \\
\text { FHAS to monitor the effectiveness of } \\
\text { engineered barriers. }\end{array}$ & FHAS \\
\hline TUNNEL 7 & $\mathrm{G}$ & $\mathrm{I}$ & $\begin{array}{l}\text { Access from Tunnel } 4 \text { to outside. No } \\
\text { piping within. }\end{array}$ & None \\
\hline BLDG 236-Z & Prite & & 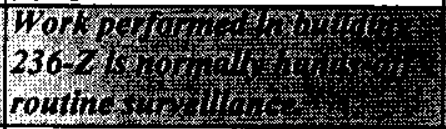 & \\
\hline CORR 10 & See Comments & $I^{*}$ & $\begin{array}{l}\text { Source term within Filter box and } \\
\text { under diamond-plated pipe trench } \\
\text { with high levels of contamination. } \\
\text { Normal configuration has E-4 } \\
\text { ventilation on pipe trench. Use FHAS } \\
\text { to monitor the effectiveness of the } \\
\text { Engineered barriers }\end{array}$ & FHAS \\
\hline CORR 11 & See Comments & $I^{*}$ & $\begin{array}{l}\text { Process Cell Glovebox within } \\
\text { Corridor. Glovebox is no longer } \\
\text { used, but gloves and port bags are still } \\
\text { present. Use FHAS to monitor the } \\
\text { effectiveness of Engineered barriers. }\end{array}$ & FHAS \\
\hline CORR 14 & See Comments & $\mathrm{I}^{*}$ & $\begin{array}{l}\text { Process Cell Glovebox within } \\
\text { Corridor. Glovebox is no longer } \\
\text { used, but gloves and port bags are still } \\
\text { present. Use FHAS to monitor the } \\
\text { effectiveness of Engineered barriers. }\end{array}$ & FHAS \\
\hline
\end{tabular}




\begin{tabular}{|c|c|c|c|c|}
\hline Pof & orimg & (6)ongancy & Gominghto, & 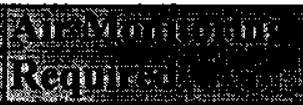 \\
\hline CORR 20 & See Comments & I* & $\begin{array}{l}\text { Filter box within room. Use FHAS to } \\
\text { monitor the effectiveness of } \\
\text { Engineered barriers. }\end{array}$ & FHAS \\
\hline CORR 21 & See Comments & $I^{*}$ & $\begin{array}{l}\text { Process Cell Glovebox within } \\
\text { Corridor. Glovebox is no longer } \\
\text { used, but gloves and port bags are still } \\
\text { present. Use FHAS to monitor the } \\
\text { effectiveness of Engineered barriers. }\end{array}$ & FHAS \\
\hline CORR 25 & See Comments & $I^{*}$ & $\begin{array}{l}\text { Process Cell Glovebox within } \\
\text { Corridor. Glovebox is no longer } \\
\text { used, but gloves and port bags are still } \\
\text { present. Use FHAS to monitor the } \\
\text { effectiveness of Engineered barriers. }\end{array}$ & FHAS \\
\hline CORR 30 & $\overline{\mathrm{G}}$ & $\mathrm{I}^{*}$ & Steam and Instrument Air Lines & None \\
\hline CORR 31 & \begin{tabular}{|l|} 
See Comments \\
\end{tabular} & $I^{*}$ & $\begin{array}{l}\text { Contaminated (sometimes- } \\
\text { pressurized) process lines. Use } \\
\text { FHAS to monitor the effectiveness of } \\
\text { Engineered barriers. Use CAMs to } \\
\text { provide early warning of airborne } \\
\text { release. }\end{array}$ & CAM, FHAS \\
\hline CORR 33 & See Comments & $I^{*}$ & $\begin{array}{l}\text { Contaminated (sometimes- } \\
\text { pressurized) process lines. Use } \\
\text { FHAS to monitor the effectiveness of } \\
\text { Engineered barriers. Use CAMs to } \\
\text { provide early warning of airborne } \\
\text { release. }\end{array}$ & CAM, FHAS \\
\hline CORR 47 & $\overline{\mathrm{G}}$ & $\mathrm{I}^{*}$ & Hallway & See Comments \\
\hline MEZZ 12A & \begin{tabular}{|l|} 
See Comments \\
\end{tabular} & $\mathrm{I}$ & $\begin{array}{l}\text { Within room } 12 \text { (Process Cell or } \\
\text { "“Canyon") }\end{array}$ & See Comments \\
\hline MEZZ 12B & See Comments & $\mathrm{I}$ & $\begin{array}{l}\text { Within room } 12 \text { (Process Cell or } \\
\text { "Canyon") }\end{array}$ & None \\
\hline RM 12 & See Comments & $I^{*}$ & $\begin{array}{l}\text { Entry requires special access control. } \\
\text { Very high levels of contamination } \\
\text { within cell area. CAMs and grab air } \\
\text { sampling required for entry. }\end{array}$ & None \\
\hline RM 13 & $\overline{\mathrm{G}}$ & $\mathrm{I}^{*}$ & $\begin{array}{l}\text { Ceiling has Process-Cell drum bag- } \\
\text { out hatch. Use FHAS to monitor the } \\
\text { effectiveness of Engineered Barriers. }\end{array}$ & $\overline{\mathrm{FHAS}}$ \\
\hline $\mathrm{RM} 15$ & $\mathrm{G}$ & $I^{*}$ & Old welding booth (no longer used) & None \\
\hline RM 16 & $\overline{\mathrm{G}}$ & $\bar{I}$ & Maintenance/Drum storage & None \\
\hline RM 17 & $\bar{G}$ & $\mathrm{I}^{*}$ & Office & None \\
\hline RM $18 \mathrm{AL}$ & $\bar{G}$ & $I^{*}$ & Air lock to outside & None \\
\hline RM 19 & $\overline{\mathrm{G}}$ & $I^{*}$ & Item loading and counting & None \\
\hline $\mathrm{RM} 26$ & See Comments & $I^{*}$ & $\begin{array}{l}\text { Source term is within wooden Filters. } \\
\text { Use FHAS to monitor the } \\
\text { effectiveness of engineered barriers. }\end{array}$ & FHAS \\
\hline RM 27 & $\mathrm{~A}$ & $\mathrm{I}^{*}$ & $\begin{array}{l}\text { Maintenance Glovebox (infrequently } \\
\text { used). Use FHAS to monitor the } \\
\text { effectiveness of Engineered Barriers. }\end{array}$ & $\begin{array}{l}\text { FHAS, (CAM } \\
\text { required when working in } \\
\text { Glovebox) }\end{array}$ \\
\hline RM 28 & \begin{tabular}{|l|} 
See Comments \\
\end{tabular} & $\overline{\mathrm{I}}$ & $\begin{array}{l}\text { Maintenance cell. Immediately } \\
\text { adjacent to corridors. Access to } \\
\text { glovebox to process cell (no longer } \\
\text { used) }\end{array}$ & None \\
\hline RM 34 & $\mathrm{G}$ & $I^{*}$ & Electrical switch room & None \\
\hline RM 35 & $\bar{G}$ & $I^{*}$ & $\begin{array}{l}\text { Pump room for } 17 \text { " sample vacuum. } \\
\text { Liquid cooling water lines. }\end{array}$ & None \\
\hline RM 36 & \begin{tabular}{|l|} 
See Comments \\
\end{tabular} & I* & $\begin{array}{l}\text { Filter Box in room. In-line CAM is } \\
\text { sampling from the filter box. }\end{array}$ & None \\
\hline$\overline{\mathrm{RM}} 3 \overline{7}$ & $\overline{\mathrm{G}}$ & $I^{*}$ & Janitor closet & None \\
\hline
\end{tabular}




\begin{tabular}{|c|c|c|c|c|}
\hline 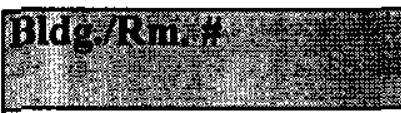 & $\begin{array}{l}\text { Conines } \\
\text { omin }\end{array}$ & Orginangy & 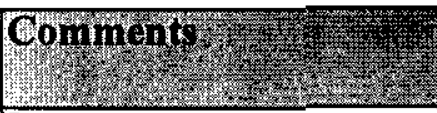 & Somblow \\
\hline RM 38 & $\mathrm{G}$ & $I^{*}$ & Rest room & None \\
\hline$\overline{R M} 39$ & See Comments & $\bar{I}$ & $\begin{array}{l}\text { aaintenance cell. Immediately } \\
\text { adjacent to corridors. Access to } \\
\text { glovebox to process cell (no longer } \\
\text { used) }\end{array}$ & None \\
\hline$\overline{\mathrm{RM}} 40$ & $\bar{G}$ & $\mathrm{I}^{*}$ & $\begin{array}{l}\text { Chemical tanks. Legacy } \\
\text { contamination is located under paint } \\
\text { in the tank basin. }\end{array}$ & None \\
\hline$\overline{\mathrm{RM}} 41$ & See Comments & $\mathrm{I}^{*}$ & $\begin{array}{l}\text { Gloveboxes within room. Some } \\
\text { gloveboxes are isolated; some } \\
\text { gloveboxes are not. Gloveboxes are } \\
\text { no longer used. Use FHAS to } \\
\text { monitor the effectiveness of } \\
\text { engineered barriers. }\end{array}$ & $\begin{array}{l}\text { FHAS, (CAM } \\
\text { required when working in } \\
\text { Glovebox) }\end{array}$ \\
\hline$\overline{R M ~ 42}$ & $\bar{D}$ & $I^{*}$ & $\begin{array}{l}\text { Column Hoods - no longer used (pie } \\
\text { plated). Use FHAS to monitor the } \\
\text { effectiveness of engineered barriers. }\end{array}$ & $\overline{\mathrm{FHAS}}$ \\
\hline$\overline{\mathrm{RM}} 43$ & $\overline{\mathrm{D}}$ & $I^{*}$ & $\begin{array}{l}\text { Glovebox no longer used (pie plated). } \\
\text { Use FHAS to monitor the } \\
\text { effectiveness of engineered barriers. }\end{array}$ & $\overline{\text { FHAS }}$ \\
\hline$\overline{\mathrm{RM}} 43 \mathrm{~A}$ & See Comments & I & $\begin{array}{l}\text { Caged area within room } 43 \text {. Subject } \\
\text { to same air sampling requirements as } \\
\text { room } 43 \text {. }\end{array}$ & See Comments \\
\hline$\overline{\mathrm{RM}} 44$ & $\bar{G}$ & $I^{*}$ & Control room & None \\
\hline$\overline{\mathrm{RM}} 45$ & $\overline{\mathrm{G}}$ & $I^{*}$ & Office & None \\
\hline$\overline{\mathrm{RM}} 50$ & $\overline{\mathrm{D}}$ & $\mathrm{I}^{*}$ & $\begin{array}{l}\text { Column Hoods - no longer used (pie } \\
\text { plated). Use FHAS to monitor the } \\
\text { effectiveness of engineered barriers. }\end{array}$ & FHAS \\
\hline$\overline{\mathrm{RM}} 60$ & $\overline{\mathrm{D}}$ & $I^{*}$ & $\begin{array}{l}\text { Column Hoods - no longer used (pie } \\
\text { plated). Use FHAS to monitor the } \\
\text { effectiveness of engineered barriers. }\end{array}$ & FHAS \\
\hline RM 70 & $\mathrm{G}$ & $\mathrm{I}$ & Access is controlled. & None \\
\hline RM 71 & $\bar{G}$ & $\bar{I}$ & Access is controlled. & None \\
\hline$\overline{\mathrm{RM}} 72$ & See Comments & I & \begin{tabular}{|l|} 
Air lock from outside to process \\
canyon. Contamination capable of \\
producing airborne contamination is \\
present. Entry requires special access \\
control. Air sampling should be \\
performed on a case-by-case basis. \\
CAMs and grab air sampling is \\
recommended for special entry.
\end{tabular} & None \\
\hline RM 73 & $\bar{G}$ & $\mathrm{I}$ & Fire Systems & None \\
\hline STR 1 & $\mathrm{G}$ & I & Stairwell & None \\
\hline STR 2 & $\bar{G}$ & $\mathrm{I}$ & Stairwell & None \\
\hline STR 3 & $\mathrm{G}$ & I & Stairwell & None \\
\hline BLDG 242-Z & 3y & 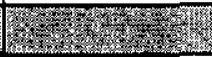 & 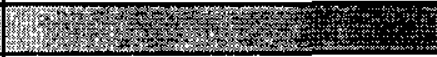 & (1) \\
\hline AIRLOCK & $\mathrm{G}$ & I & Normal PRF access & None \\
\hline CORR 242B & $\bar{G}$ & I & Normal PRF access & None \\
\hline ALL OTHERS & See Comments & I & $\begin{array}{l}\text { Access is restricted, and requires } \\
\text { special entry. Site of resin column } \\
\text { explosion in the } 1970 \text { 's (AKA the } \\
\text { McKlusky room). Gloveboxes are } \\
\text { located within room. This area was } \\
\text { used for Am-24l separations from } \\
\text { various waste streams. Am-24l is the } \\
\text { primary isotope of concem. This area } \\
\text { is considered highly contaminated. }\end{array}$ & None \\
\hline BLDG 291-Z & 28 & & 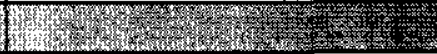 & 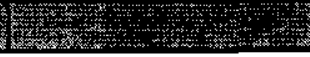 \\
\hline
\end{tabular}




\begin{tabular}{|c|c|c|c|c|}
\hline BWG & Source & Oocupancy & Gommerite & Whandsh \\
\hline CABLE VAULT & G & I & Electrical Equipment & None \\
\hline RM 500 & $\overline{\mathrm{G}}$ & II & Electrical Equipment & None \\
\hline RM 501 & See Comments & $\overline{\mathrm{II}}$ & $\begin{array}{l}\text { Sump Room. Historically } \\
\text { Contaminated - use FHAS to monitor } \\
\text { effectiveness of Engineered Barriers. }\end{array}$ & FHAS \\
\hline RM 502 & See Comments & $\overline{\text { II }}$ & $\begin{array}{l}\text { Fan Room. Contains degrading } \\
\text { ducting from Building } 232-Z \text {. Use } \\
\text { FHAS to monitor the effectiveness of } \\
\text { Engineered Barrier. }\end{array}$ & FHAS \\
\hline RM 503 & $\bar{G}$ & I & $\begin{array}{l}\text { Below surface of } 502 \text {. Not normally } \\
\text { accessed. }\end{array}$ & None \\
\hline RM 504 & See Comments & $\mathrm{I}$ & Plenum. Non accessible. & None \\
\hline RM 505 & See Comments & I & Plenum. Non accessible. & None \\
\hline$\overline{R M} 506$ & See Comments & $\bar{I}$ & $\begin{array}{l}\text { Fan Room. Contains degrading } \\
\text { ducting from Building } 232-Z \text {. Use } \\
\text { FHAS to monitor the effectiveness of } \\
\text { Engineered Barrier. }\end{array}$ & FHAS \\
\hline RM 507 & \begin{tabular}{|l|} 
See Comments \\
\end{tabular} & I & $\begin{array}{l}\text { Final Exhaust plenum manhole } \\
\text { access. Requires special entry } \\
\text { controls. }\end{array}$ & None \\
\hline RM 508 & $\bar{G}$ & $\bar{I}$ & Manhole. Difficult to access. & None \\
\hline RM 509 & \begin{tabular}{|l|} 
See Comments \\
\end{tabular} & III & $\begin{array}{l}\text { Fan Room. Contains degrading } \\
\text { ducting from Building } 232-Z \text {. Use } \\
\text { FHAS to monitor the effectiveness of } \\
\text { Engineered Barrier. }\end{array}$ & FHAS \\
\hline RM 510 & $\bar{G}$ & $\bar{I}$ & $\begin{array}{l}\text { Below surface of 509. Not normally } \\
\text { accessed. }\end{array}$ & None \\
\hline STR 1 & $\bar{G}$ & $\mathrm{I}$ & Stairwell & None \\
\hline STR 2 & $\bar{G}$ & I & Stairwell & None \\
\hline STR 3 & $\bar{G}$ & $\mathrm{I}$ & Stairwell & None \\
\hline BLDG 2736-Z & - & 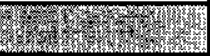 & Why & 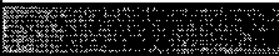 \\
\hline VAULT CORR & G & II & Corridor to Vaults & None \\
\hline VAULT 1 & $\bar{F}$ & $\mathrm{I}^{*}$ & Vault & CAM \\
\hline VAULT 2 & $\overline{\mathrm{F}}$ & II* & Vault & CAM \\
\hline VAULT 3 & $\bar{F}$ & $\mathrm{II}^{*}$ & Vault & CAM \\
\hline VAULT 4 & $\bar{F}$ & $I^{*}$ & Vault & CAM \\
\hline $2736 \mathrm{ZAL}$ & $\overline{\mathrm{G}}$ & I & Air lock to Corridor (outside access) & None \\
\hline CORR $625 \mathrm{AL}$ & $\overline{\mathrm{G}}$ & $\mathrm{I}$ & \begin{tabular}{|l|l} 
Air lock to Corridor \\
\end{tabular} & None \\
\hline BLDG 2736-ZB & 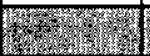 & 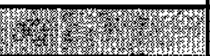 & 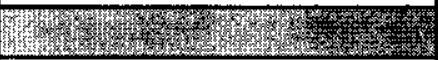 & $y_{2}$ \\
\hline CORR 601 & $\mathrm{G}$ & I & Corridor & None \\
\hline CORR 609 & $\bar{G}$ & $\mathrm{I}$ & Corridor & None \\
\hline CORR 617 & $\bar{G}$ & $\mathrm{I}$ & Corridor & None \\
\hline$\overline{\mathrm{RM}} 600$ & See Comments & $\bar{I}$ & $\begin{array}{l}\text { Filter boxes within room. Use FHAS } \\
\text { to monitor the effectiveness of } \\
\text { Engineered Barriers. }\end{array}$ & FHAS \\
\hline RM 602 & $\bar{G}$ & $\mathrm{I}$ & Electrical & None \\
\hline RM 603 & $\bar{G}$ & III & Office & None \\
\hline RM 604 & $\bar{G}$ & II & Computer room & None \\
\hline RM 605 & $\mathrm{G}$ & IIII & Office & None \\
\hline RM 606 & $\bar{G}$ & III & Office & None \\
\hline RM 607 & $\bar{G}$ & III & Office & None \\
\hline
\end{tabular}




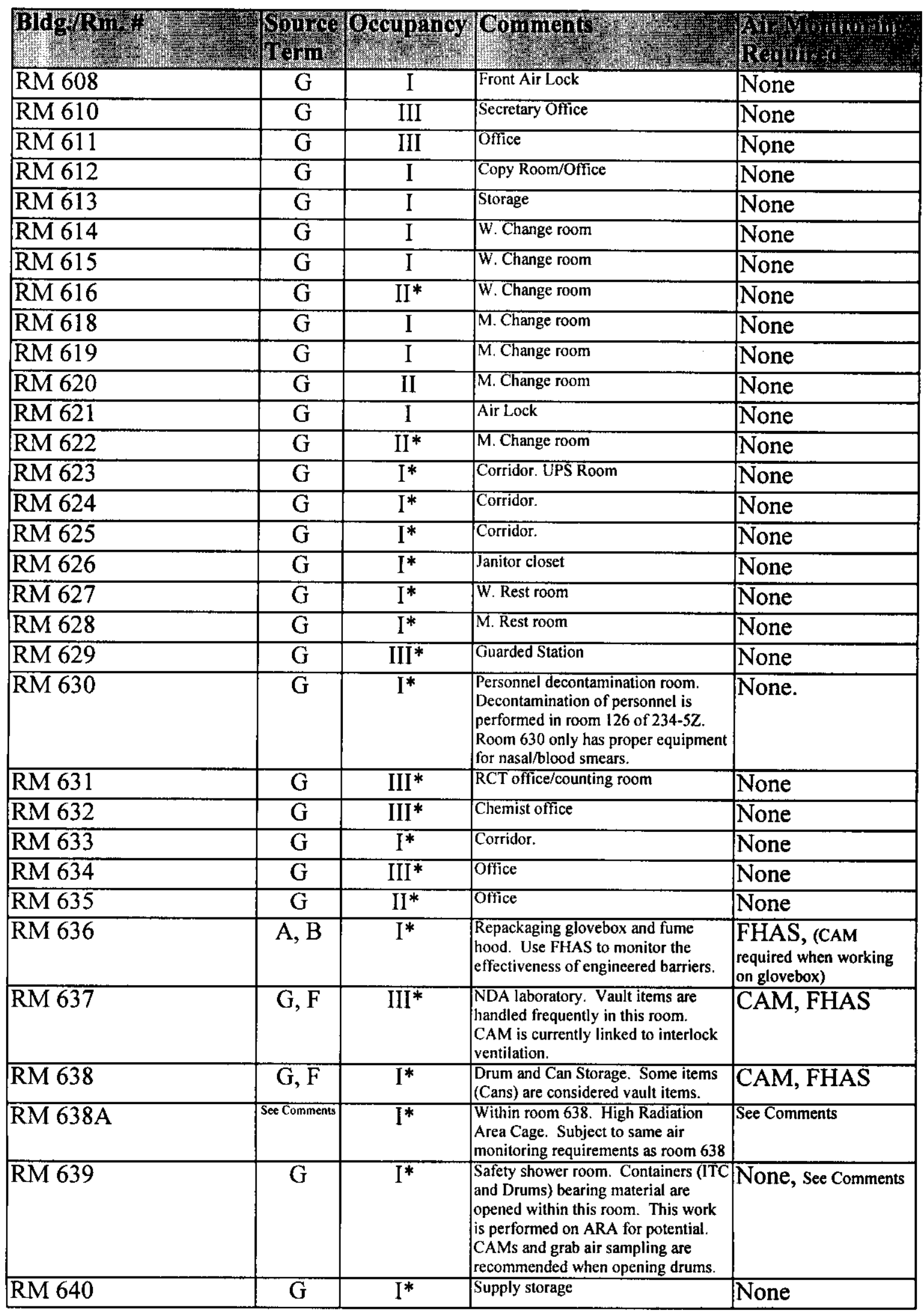




\begin{tabular}{|c|c|c|c|c|}
\hline $\mathrm{W} / \mathrm{W} / \mathrm{b}$ & Whoringer & Oropang & Coniments) & Wonom \\
\hline RM 641 & $\mathrm{G}$ & $I^{*}$ & $\begin{array}{l}\text { Receiving room / Drum Storage. } \\
\text { Use FHAS to monitor the } \\
\text { effectiveness of engineered barriers. } \\
\text { Containers (ITC and Drums) bearing } \\
\text { material are opened within this room. } \\
\text { This work is performed on ARA for } \\
\text { potential airborne contamination. } \\
\text { CAMs and grab air sampling are } \\
\text { recommended when opening drums. }\end{array}$ & $\begin{array}{l}\text { FHAS, See } \\
\text { Comments }\end{array}$ \\
\hline RM 641A & $\mathrm{G}$ & I & $\begin{array}{l}\text { With in Room } 641 \text { (Electrical } \\
\text { Components) }\end{array}$ & None \\
\hline RM 642 & $\mathrm{G}$ & $I^{*}$ & Shipping room & None \\
\hline RM 643 & $\mathrm{G}$ & $I^{*}$ & Personnel entry & None \\
\hline RM 644 & $\bar{G}$ & $I^{*}$ & Material passageway & None \\
\hline RM 645 & $\bar{G}$ & $\bar{I}$ & Entrance to Computer Room & None \\
\hline RM 646 & $\mathrm{G}$ & I & Entrance to $W$. Change room & None \\
\hline $\begin{array}{l}\text { OTHER } \\
\text { BUILDINGS }\end{array}$ & 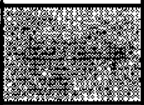 & P. & Mrim & $x^{2}+2$ \\
\hline 234-5 ZA & $\mathrm{G}$ & III & $\begin{array}{l}\text { Building houses M. Locker rooms, } \\
\text { Primary ACES station and Secured } \\
\text { entry to 234-5 } \mathrm{Z} \text { main building. } \\
\end{array}$ & None \\
\hline 225-WC & $\mathrm{G}$ & I & Liquid Effluent Sampling & None \\
\hline 234-ZB & $\bar{G}$ & I & Construction Shop & None \\
\hline $241-Z$ & $\mathrm{G}$ & $\mathrm{I}^{*}$ & $\begin{array}{l}\text { Ventilation/Operating area. Pits may } \\
\text { not be entered without special work } \\
\text { planning. CAMs and grab air } \\
\text { sampling are recommended when } \\
\text { entering. }\end{array}$ & None \\
\hline 241-ZG & $\mathrm{G}$ & I & Change room & None \\
\hline 241-ZB & $\mathrm{G}$ & I & Chemical tanks & None \\
\hline 241-ZA & $\mathrm{A}, \mathrm{D}$ & $\mathrm{I}^{*}$ & $\begin{array}{l}\text { Sampling gloveboxes within room for } \\
\text { sampling liquid effluent. Small } \\
\text { glovebox is isolated and no longer } \\
\text { used. Large glovebox does not have } \\
\text { enough source term to cause airbome. }\end{array}$ & None \\
\hline 243-Z & $\mathrm{G}$ & $\mathrm{I}$ & Effluent & None \\
\hline 243-ZA & $\mathrm{G}$ & $\mathrm{I}$ & Overflow tank and sump pit & None \\
\hline 270-Z & $\mathrm{G}$ & III & Administrative Building & None \\
\hline 2701-ZA & $\bar{G}$ & III & Patrol & None \\
\hline 2701-ZD & $\mathrm{G}$ & III & Guard shack & None \\
\hline 2704-Z & $\bar{G}$ & III & Safeguards and Security personnel & None \\
\hline 2705-Z & $\mathrm{G}$ & III & OCF & None \\
\hline 2712-Z & $\mathrm{G}$ & I & Stack CAM shed & None \\
\hline 2715-Z & $\mathrm{G}$ & II & Carpenter/painter shed & None \\
\hline 2721-Z & $\bar{G}$ & I & Diesel generator & None \\
\hline 2727-Z & $\mathrm{G}$ & $\mathrm{I}$ & Shed & \begin{tabular}{|l|} 
None \\
\end{tabular} \\
\hline 2729-Z & $\mathbf{G}$ & III & Insulator shop & None \\
\hline $2731-Z$ & $\mathrm{G}$ & $\mathrm{I}$ & Laundry Storage & None \\
\hline 2731-ZA & $\mathrm{G}$ & $\mathrm{I}$ & Non radiological storage & None \\
\hline 2734-Z & $\bar{G}$ & I & Gas storage & None \\
\hline 2734-ZL & $\mathrm{G}$ & $\mathrm{I}$ & Electrical & None \\
\hline
\end{tabular}




\begin{tabular}{|c|c|c|c|c|}
\hline Bdghing & Borrese & Oroupancy & Comingit & Promonom \\
\hline $2735-Z$ & $\mathrm{G}$ & I & Non radiological tanks and basin & None \\
\hline$\overline{2736-Z C}$ & $\overline{\mathrm{G}}$ & $\mathrm{I}$ & Drum Dock & None \\
\hline $2736-Z A$ & $\bar{G}$ & I & $\begin{array}{l}\text { OSR In-line monitoring of Filter } \\
\text { Boxes }\end{array}$ & None \\
\hline $2904-\mathrm{ZA}$ & $\bar{G}$ & I & Discontinued Effluent sampling & None \\
\hline $2904-Z B$ & $\overline{\mathrm{G}}$ & I & Discontinued Effluent sampling & None \\
\hline MO-14 & $\bar{G}$ & $\bar{I}$ & Sign-painters office/shop & None \\
\hline MO-287 & $\bar{G}$ & III & Mobile Office/trailer & None \\
\hline $\mathrm{MO}-428$ & $\bar{G}$ & III & Mobile Office/trailer & None \\
\hline MO-429 & $\bar{G}$ & III & $\begin{array}{l}\text { Solid Waste Operations trailer and } \\
\text { Emergency personnel } \\
\text { decontamination room. This is } \\
\text { primarily used for nasal/blood smears. }\end{array}$ & None \\
\hline$\overline{\text { TC-66 }}$ & $\bar{G}$ & I & Unused airlock to $242-\mathrm{Z}$ & None \\
\hline$\overline{Z-9}$ & See Comments & I & $\begin{array}{l}\text { Old Crib building. Gloveboxes are } \\
\text { isolated and ventilation is } \\
\text { disconnected (also disconnected to } \\
\text { building). Recommend Grab Air } \\
\text { Sampling for entry when posted } \\
\text { ARA. }\end{array}$ & None \\
\hline JAJ 64-15332 & $\bar{G}$ & III & Construction Trailers & None \\
\hline JAJ 64-15305 & $\overline{\mathrm{G}}$ & III & Construction Trailers & None \\
\hline 2734-ZB & $\mathrm{G}$ & $\mathrm{I}$ & Q-ONSET Hut & None \\
\hline & & & & \\
\hline & & & & \\
\hline & & & & \\
\hline & & & & \\
\hline & & & & \\
\hline & & & & \\
\hline
\end{tabular}

* Occupancy information obtained from Table 8-14 of the PFP FSAR

\section{Required Review}

Facility Radiological Control shall perform and document a review of the adequacy of work place air monitoring systems as part of facility or operational changes affecting radiological control. In the absence of such changes, a review should be conducted annually. When changes to the work place air monitoring program do occur, the facility should update the work place air monitoring technical basis document to reflect the changes. Re-evaluate airflow patterns in a given area when facility changes occur that may affect airflow or every three years, as needed. 


\section{References}

\subsection{Facility Air Monitoring References}

WHC-SD-CP-SDD-011 "Definition and Means of Maintaining the Room Continuous Air Monitors Portion of the PFP Safety Envelope"

HNF-SD-CP-SAR-021 "Plutonium Finishing Plant Final Safety Analysis Report"

HNF-EP-0924: 1997, M.S. Gerber, "History and Stabilization of the Plutonium Finishing Plant (PFP) Complex, Hanford Site"

FSP-PFP-IP-003: 1999, A.L. Ehlert, "Radiological History of the Plutonium Finishing Plant (1954-1997)"

WHC-SD-CP-TI-190: 1994, RD Crowe and RW Szempruch, "Technical Basis for Characterization of Plutonium for PFP Safety Analysis"

FSP-PFP-5-8, Section 14.18 "Trending Air Sample Data"

FSP-PFP-5-8, Section 14.8 "Radiological Area Occupancy During Support System Outages"

ZRC-100-002 "Initial CAM Setup and Weekly Performance Testing"

ZRC-100-003 "Daily CAM Operational Checks"

ZRC-100-004 "Grab Air Sampling"

ZRC-100-005 "Operation of Staplex High Volume Air Sampler with Kinetic Impactor"

ZRC-100-009 "Continuous Air Monitor (CAM) Alarm Response for Breathing Air" 


\subsection{General References}

Title 10, Code of Federal Regulations (CFR), Part 835 "Occupational Radiation Protection"

Hanford Site Radiological Control Manual

HNF-PRO-330 "Work Place Air Monitoring"

HNF-PRO-332 "Radon"

HNF-PRO-380 "Internal Dosimetry Program" 
7. Appendices 
HNF-5242 Row O

A)

Appendix A

Constant Air Monitor Stations 


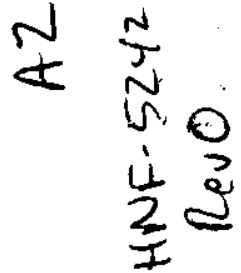
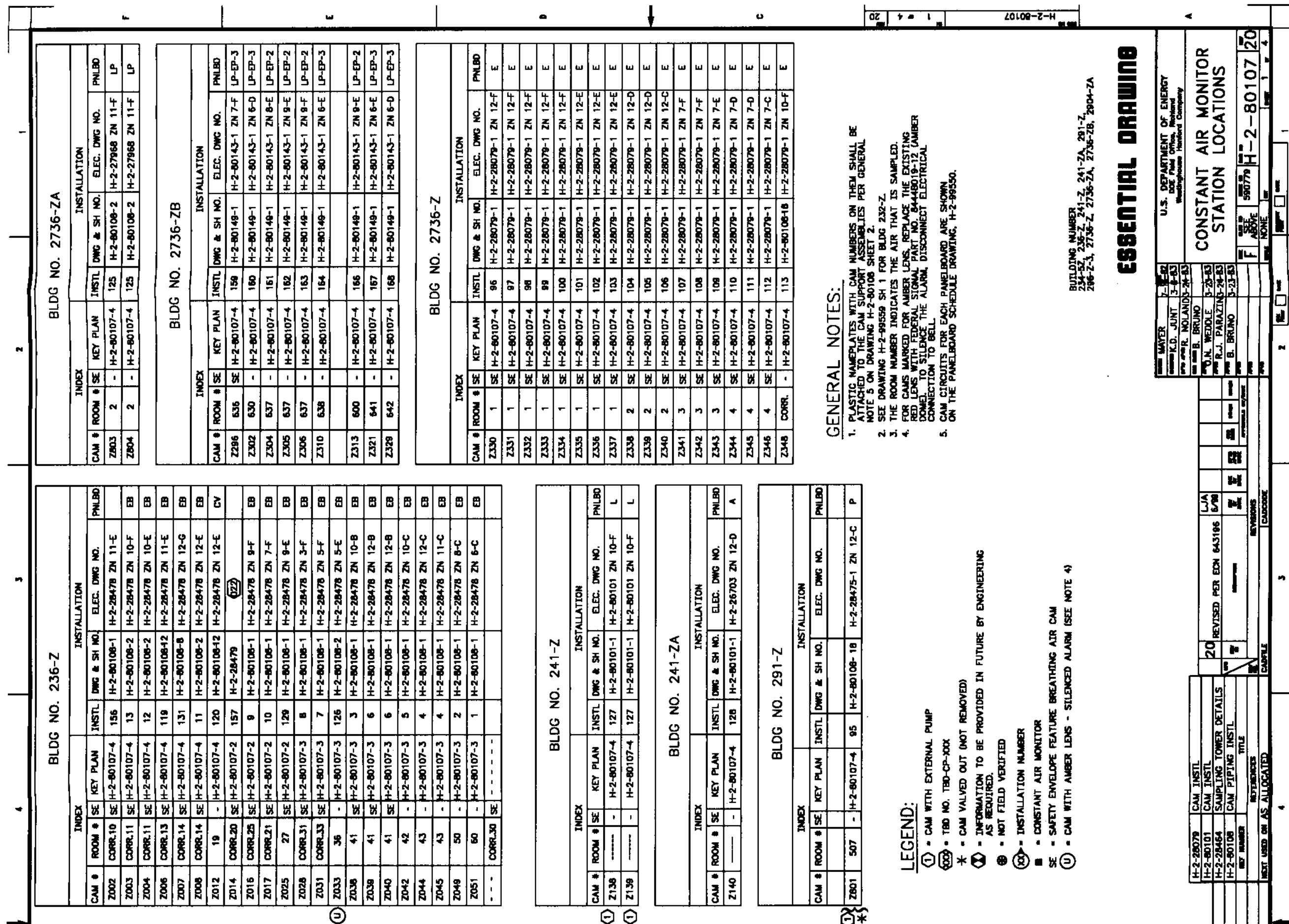

\begin{tabular}{|l|l|}
\hline & 1 \\
\hline & 1 \\
\hline & $\mathbf{4}$ \\
\hline & \\
\hline & \\
\hline
\end{tabular}

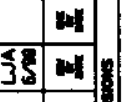

중

空

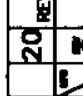

N

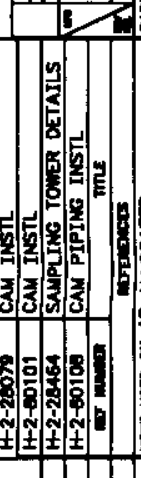

产

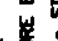

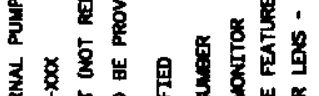

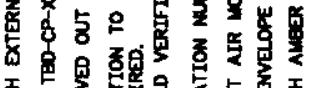

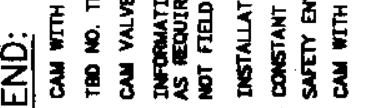

刨家* -

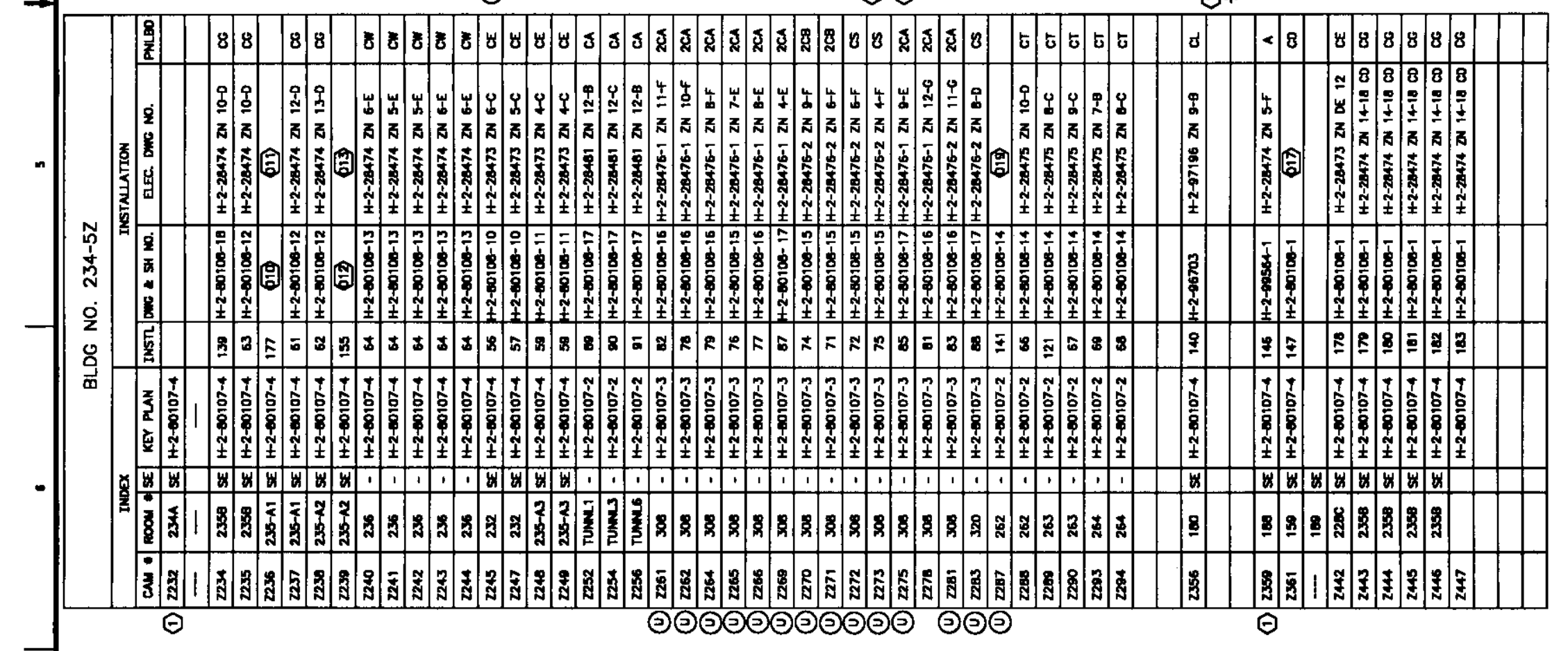

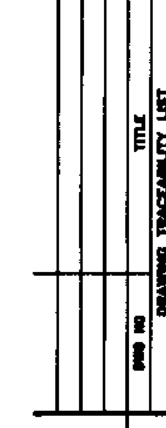

ฐิ

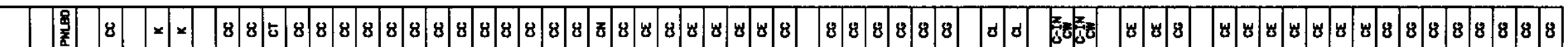

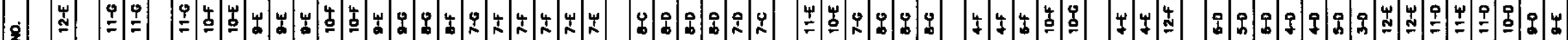

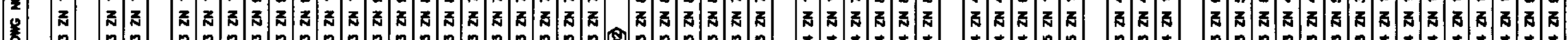

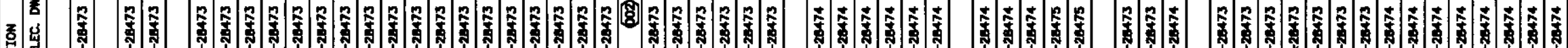

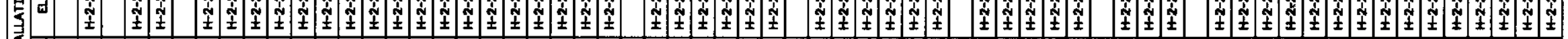

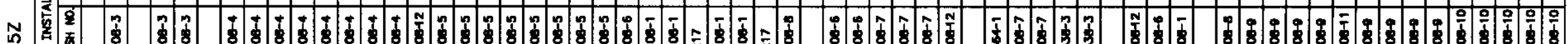
志 令

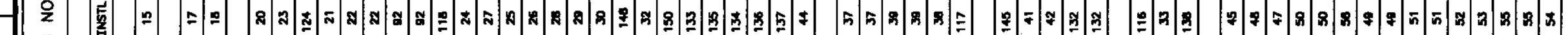
递

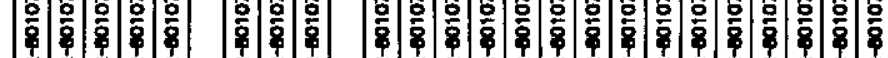
可

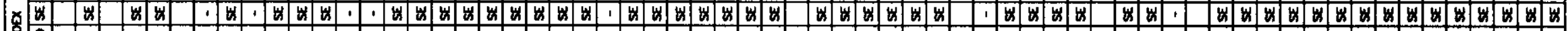

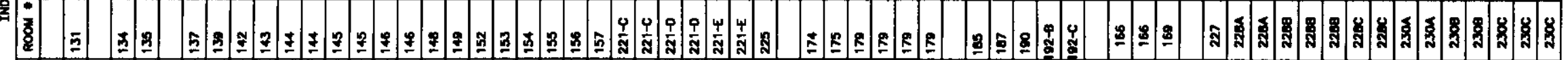

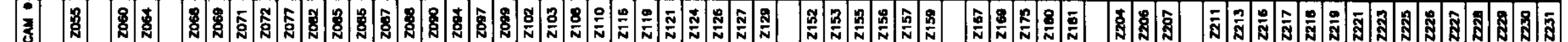




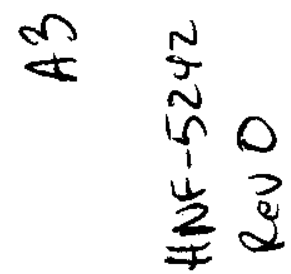

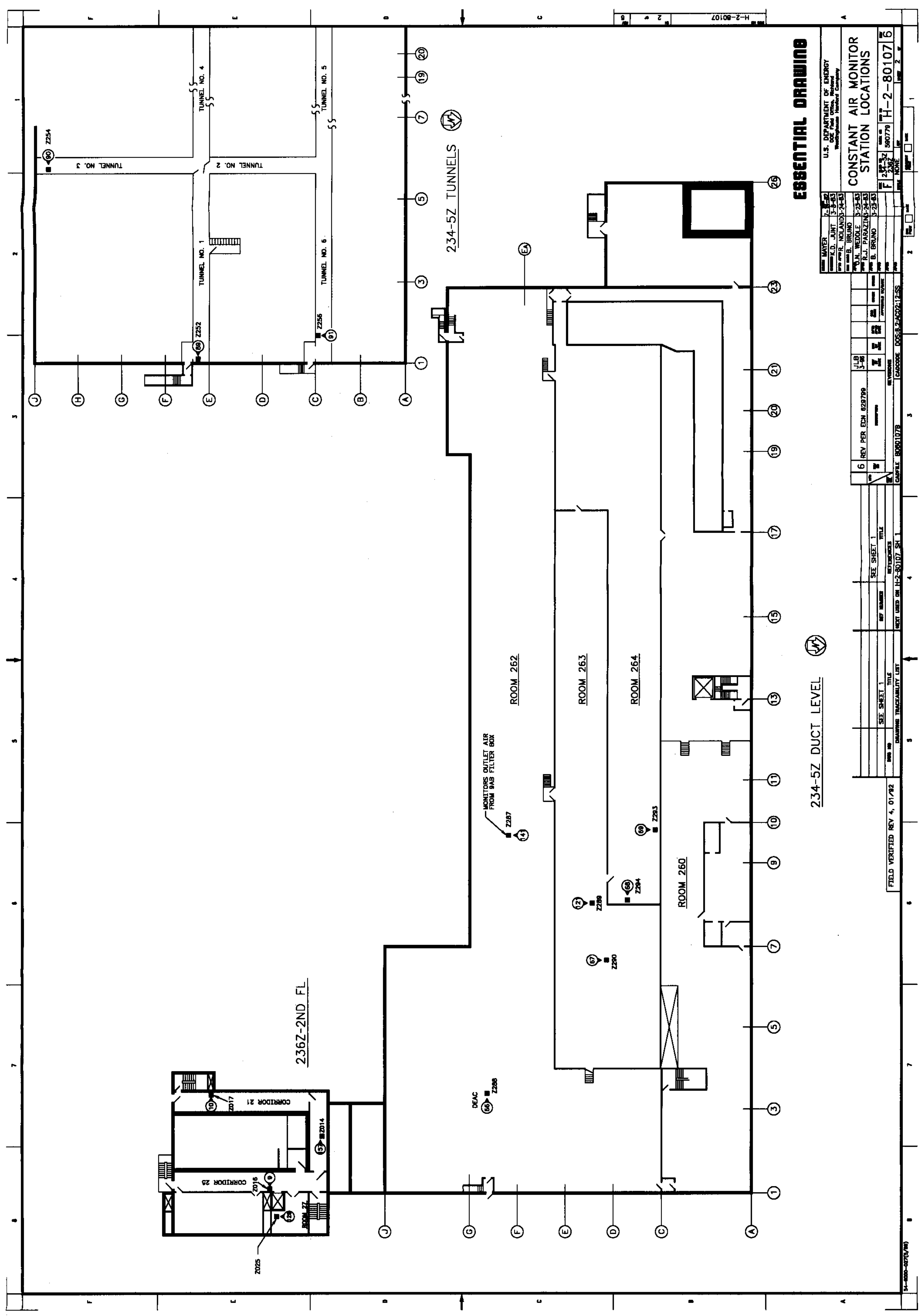




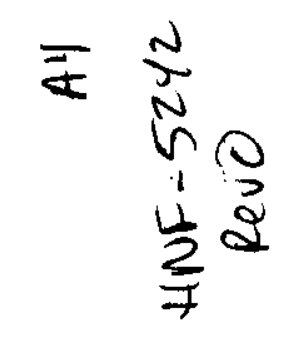

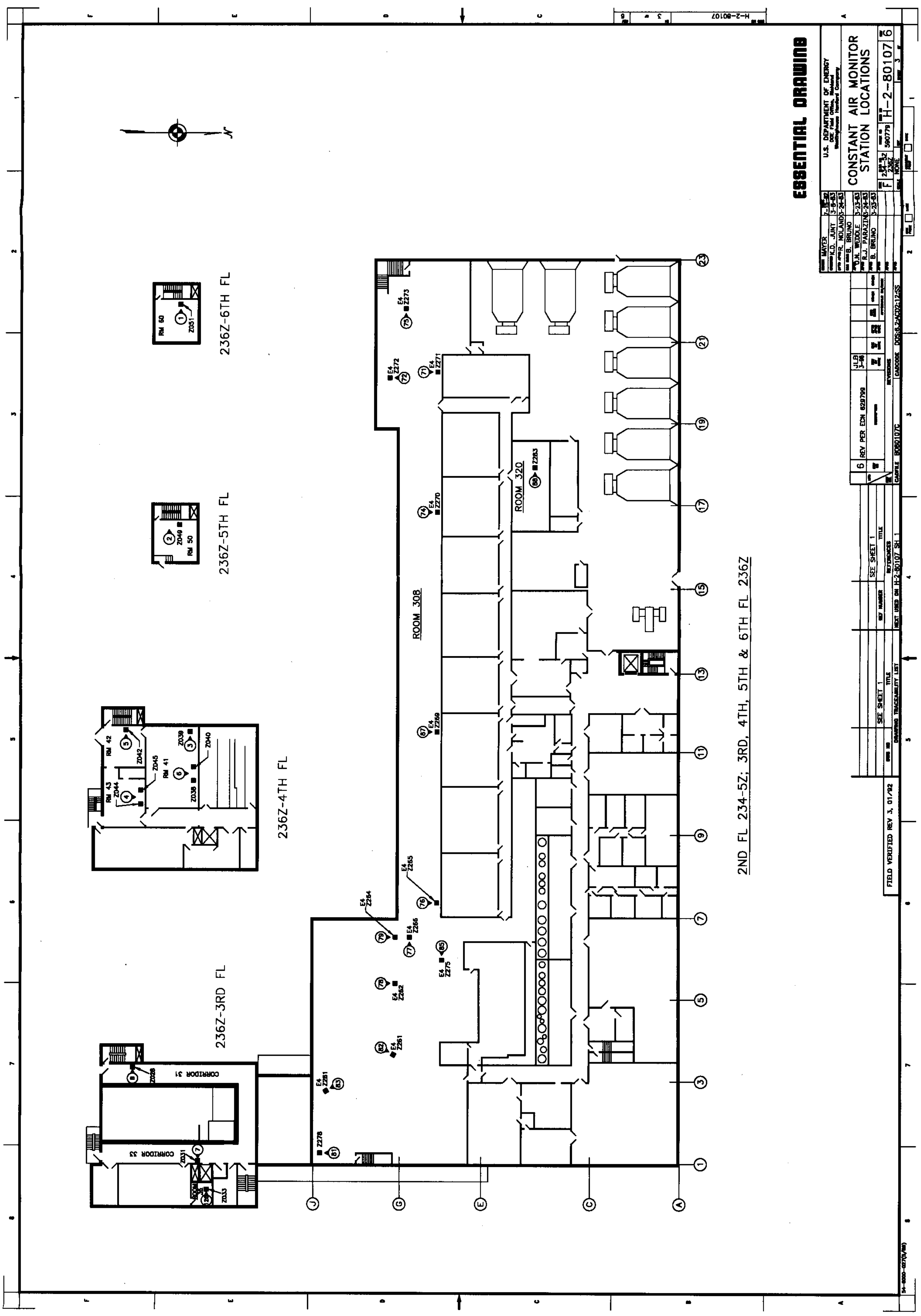




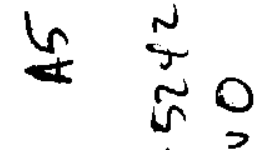

$$
\begin{aligned}
& \text { 岸 }
\end{aligned}
$$

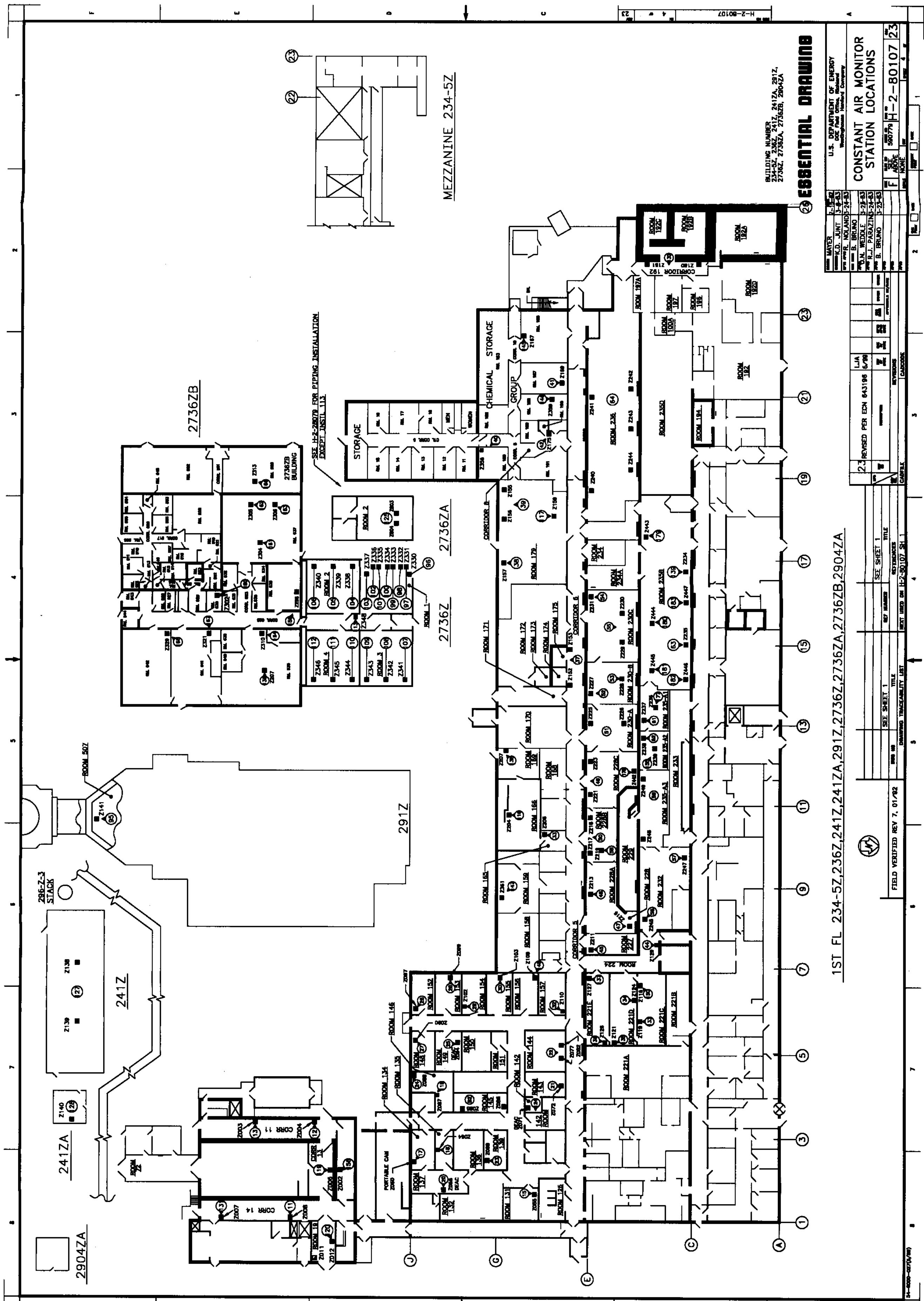


HNF-S24Z 28.0

BI

Appendix B

Air Sampling Stations 

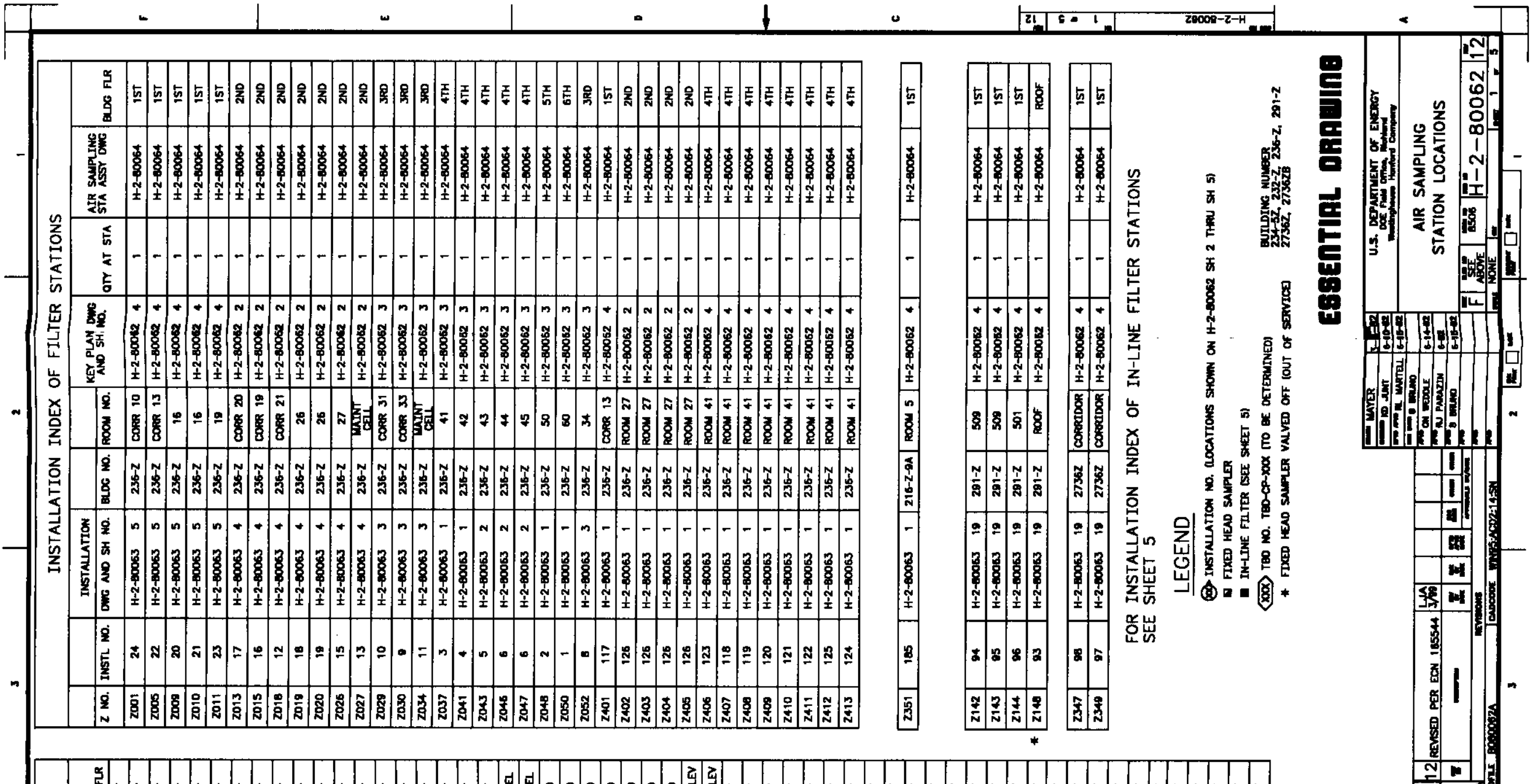

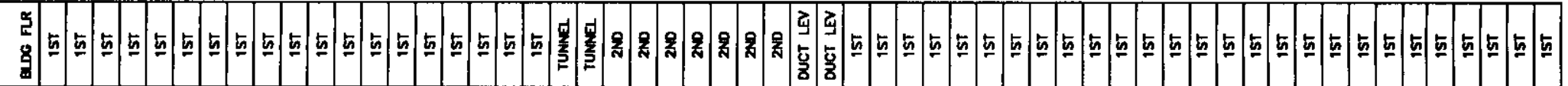
笨

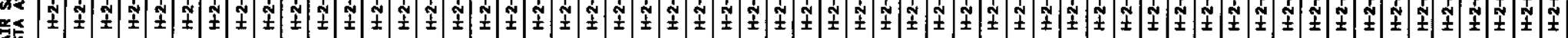

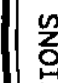
究

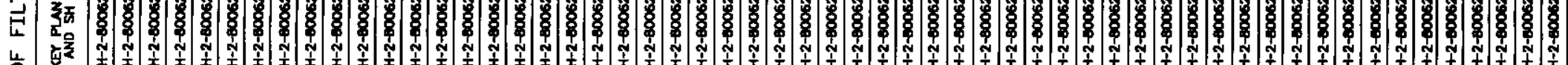

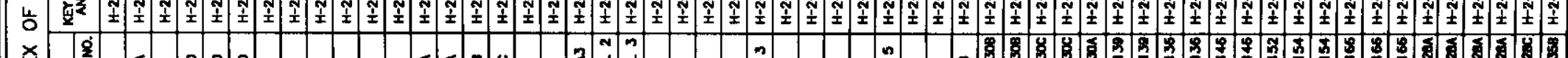
若

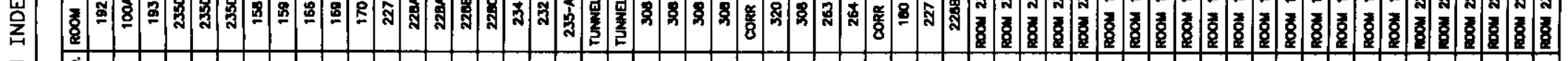

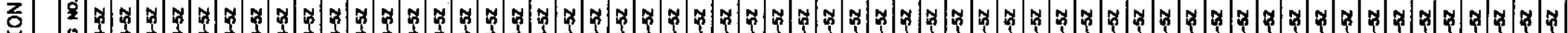

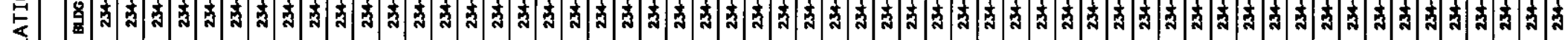

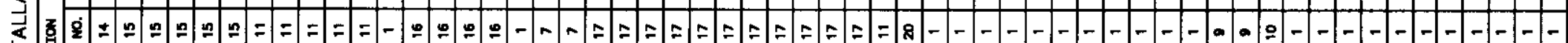

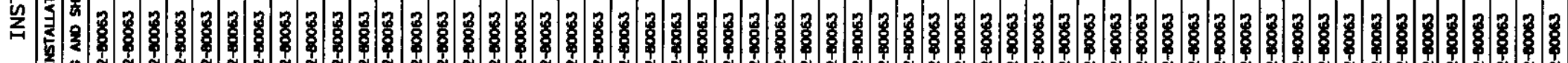

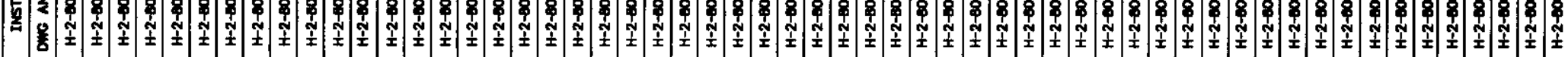

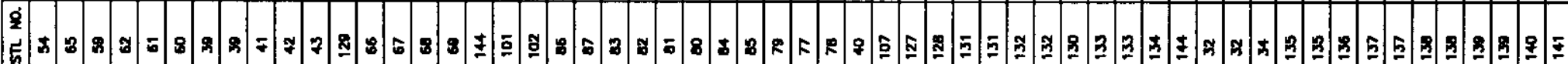

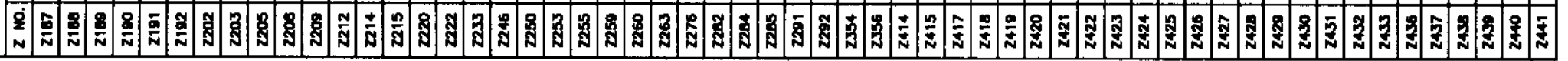

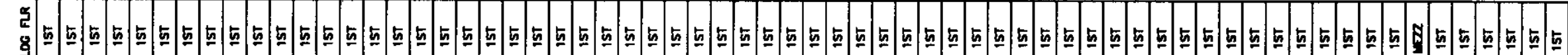
㩆

影存 20

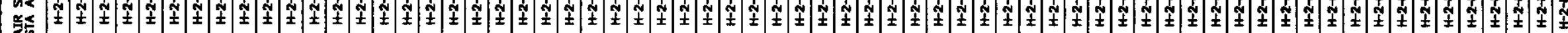

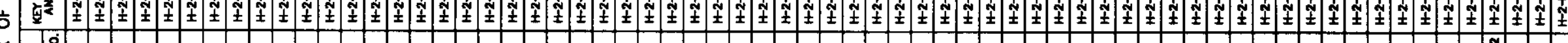

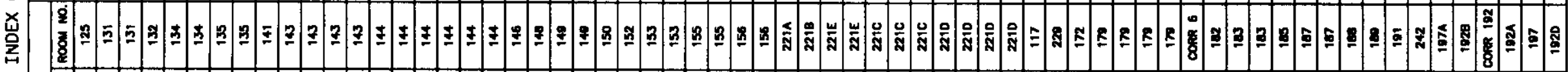
z

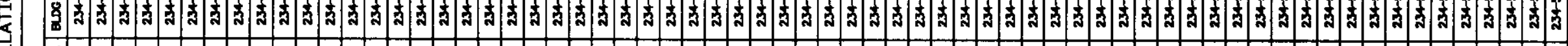

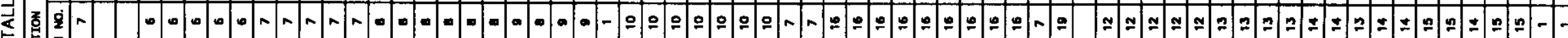

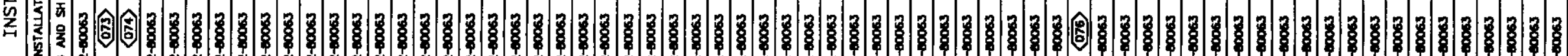

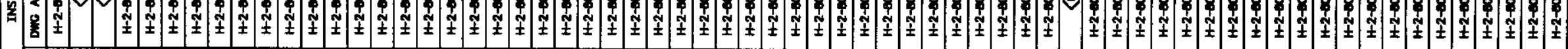

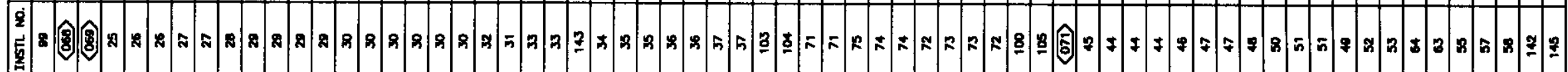

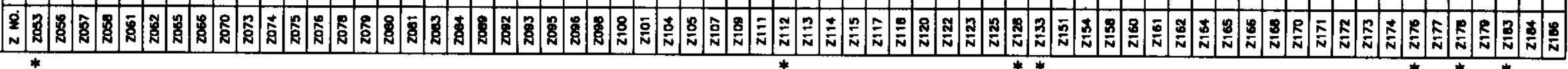


m

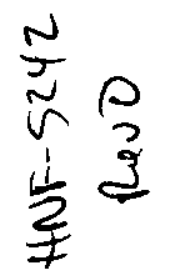

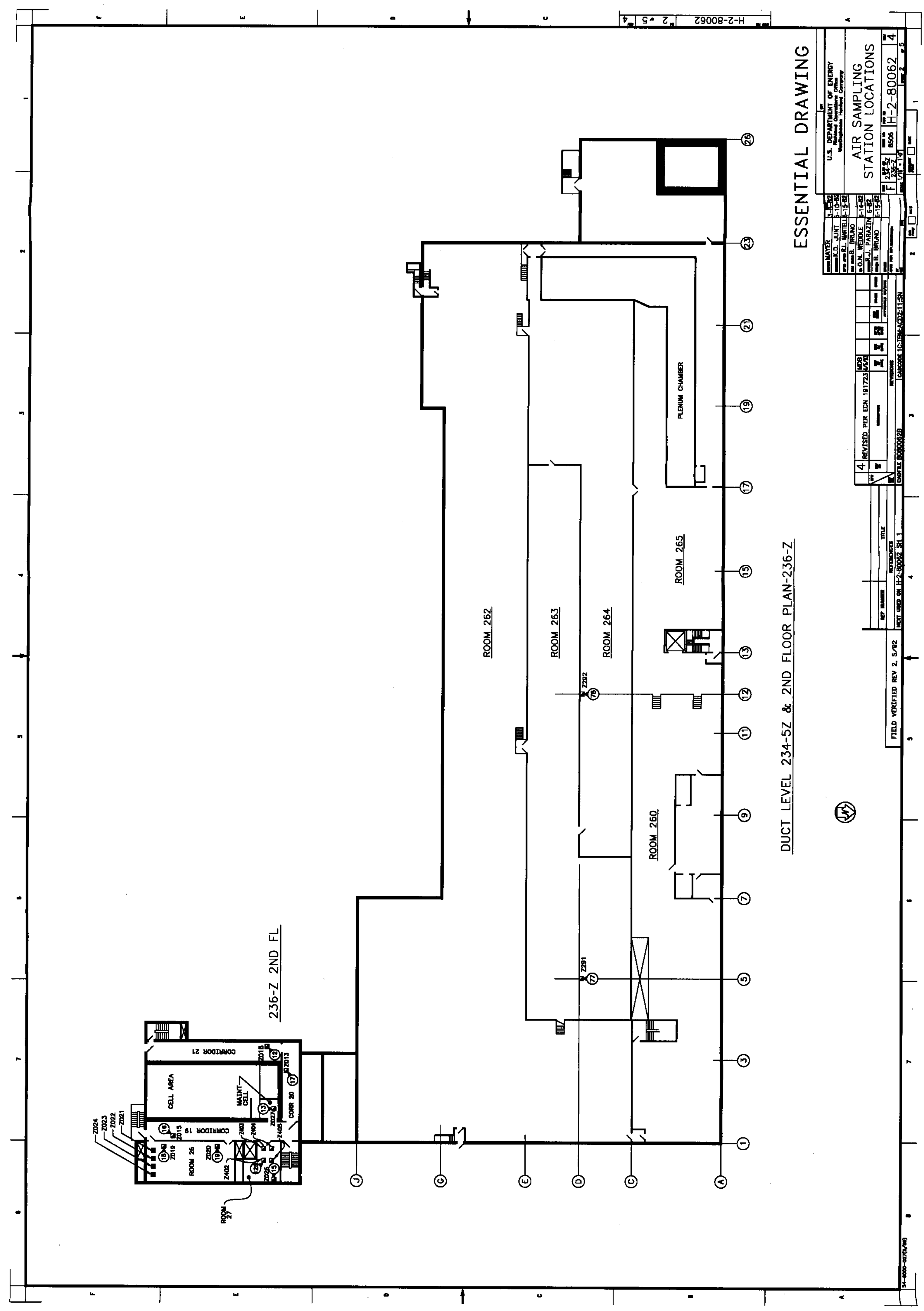




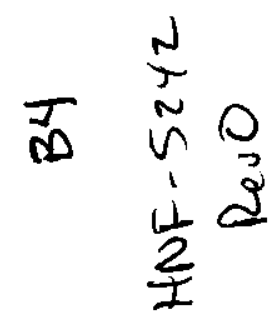

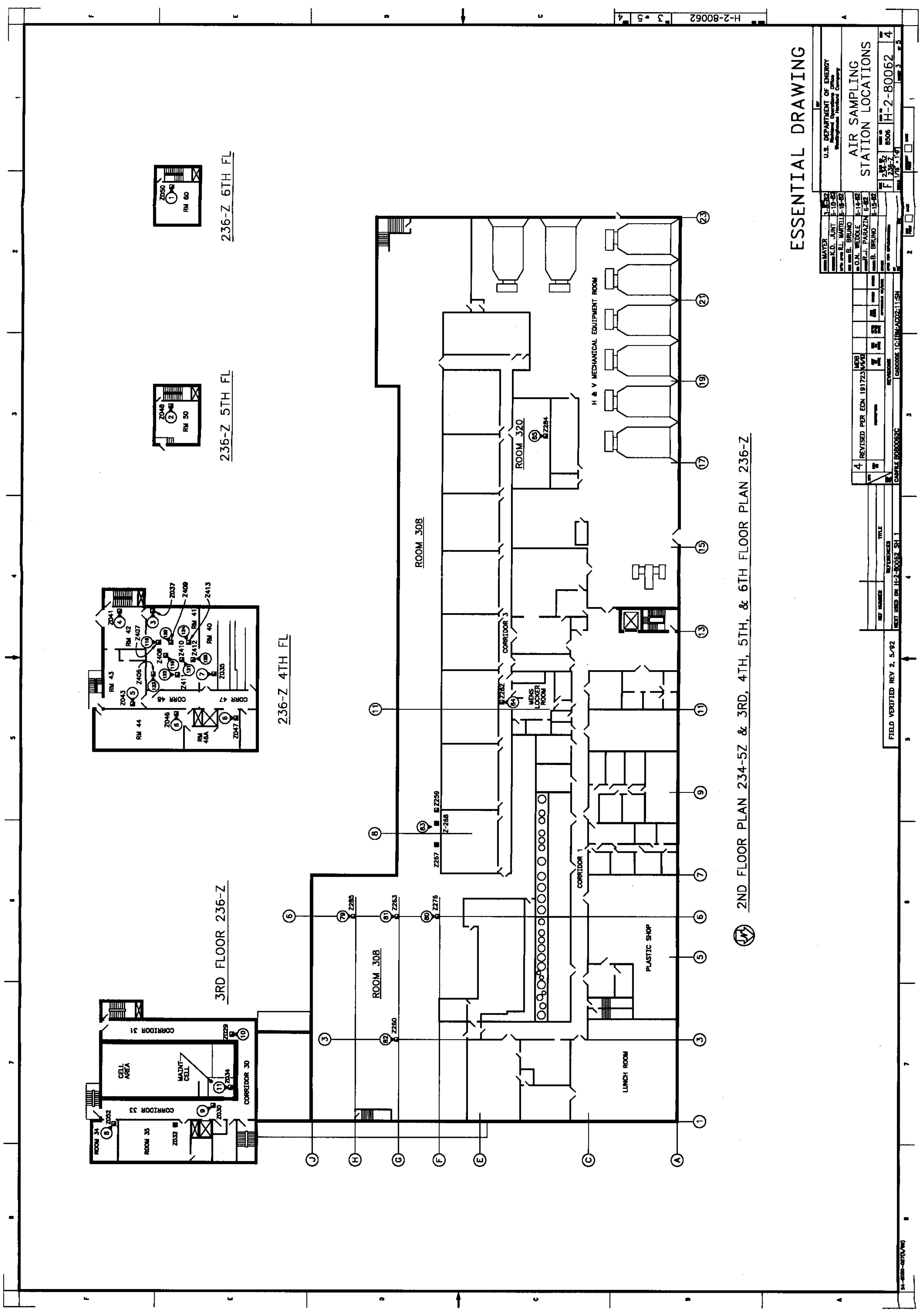




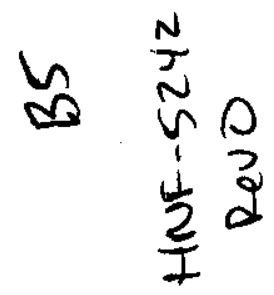

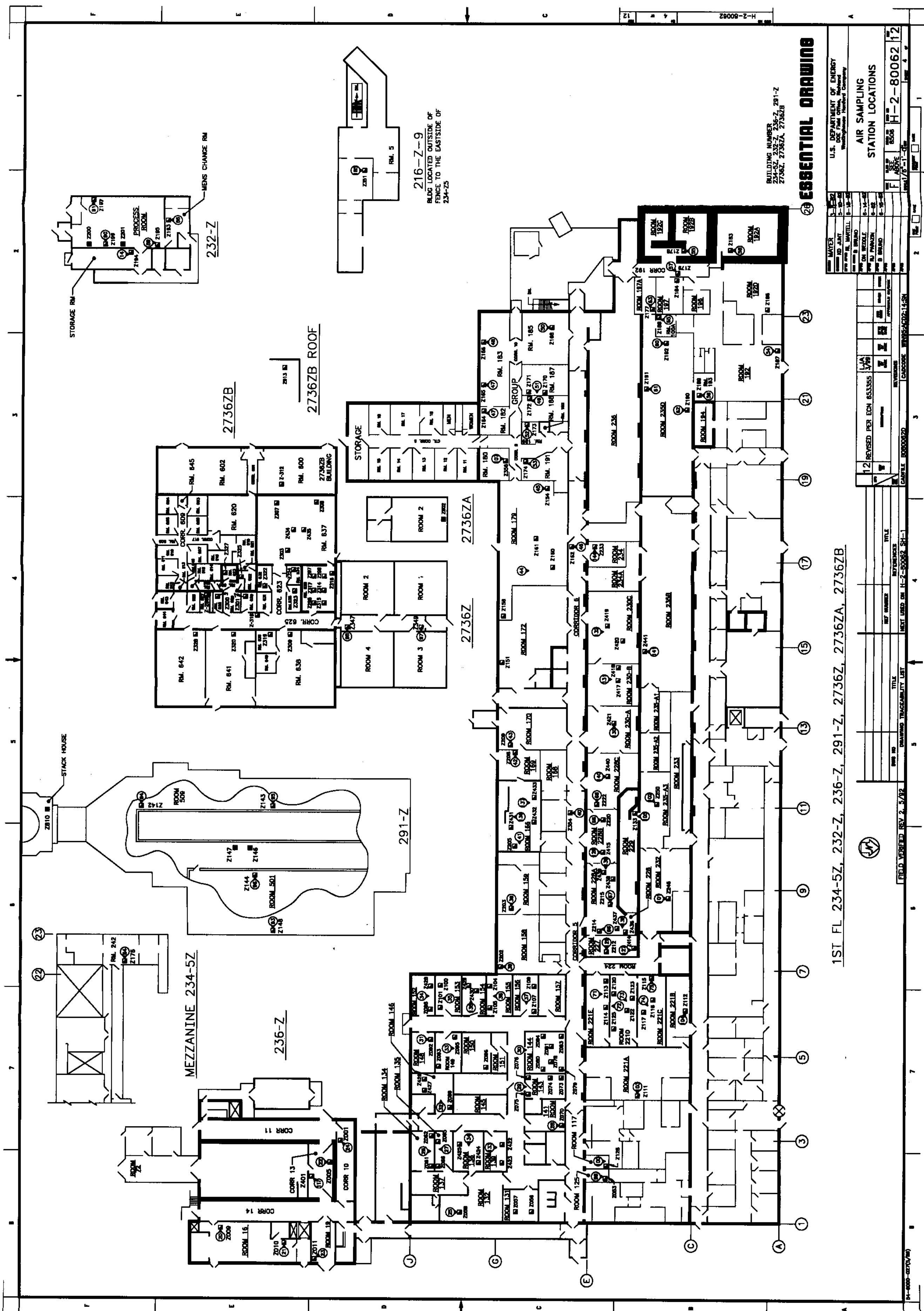




\section{DISTRIBUTION SHEET}

To

Distribution

Project Title/Work Order

HNF-5242, Rev. 0. "Technical Basis for Work Place Air Monitoring at the Plutonium Einishing Plant (PFP)"

\begin{tabular}{l} 
\\
\hline RA Jones \\
\hline TD Merkling \\
WF White \\
\hline DA Conners \\
BS tharder \\
RS Jansons \\
\hline PA Oben \\
TJ Froelich \\
\hline KA Consani \\
\hline Centralfiles \\
\hline
\end{tabular}

From
RA Jones

(1)

\section{Name}

$2+2$

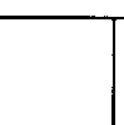

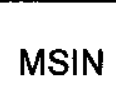

MSIN

(2)

\begin{tabular}{|c|c}
\hline MSIN & $\begin{array}{c}\text { Text } \\
\text { With All } \\
\text { Attach. }\end{array}$ \\
\hline$T 5-57$ & $x$ \\
\hline$T 5-57$ & $x$ \\
\hline$T 4-20$ & $x$ \\
\hline $75-11$ & $x$ \\
\hline$T 5-57$ & $x$ \\
\hline$T 5-57$ & $x$ \\
\hline$A 0-24$ & $x$ \\
\hline$A 0-24$ & $x$ \\
\hline$T 5-57$ & $x$ \\
\hline$B 1-07$ & $x$ \\
\hline
\end{tabular}

Page 1 of

Date $10 / 04 / 1999$

EDT No. 627528

ECN No. NA

\begin{tabular}{|c|c|}
\hline Text Only & $\begin{array}{l}\text { Attach.I } \\
\text { Appendix } \\
\text { Only }\end{array}$ \\
\hline
\end{tabular}

